Article

\title{
Does the Conceptualization and Measurement of Democracy Quality Matter in Comparative Climate Policy Research?
}

\author{
Romy Escher* and Melanie Walter-Rogg \\ Department for Political Science Research Methods, Institute of Political Science, University of Regensburg, \\ 93040 Regensburg, Germany; E-Mails: romy.escher@ur.de (R.E.), melanie.walter-rogg@ur.de (M.W.-R.) \\ * Corresponding author
}

Submitted: 29 September 2017 | Accepted: 7 December 2017 | Published: 19 March 2018

\begin{abstract}
Previous empirical research on democracy and global warming has mainly questioned whether democracy contributes to climate protection. However, there is no consensus in the theoretical literature on what institutional traits of democracy are crucial for climate policy. Thus, results based on indices that summarize multiple democracy quality dimensions could be misleading, as their effects could balance each other out or hide the relative importance of each institutional trait. This article examines whether the analysis of the effects of democracy quality dimensions, measured by separate indicators, contributes to a better understanding of cross-national variance in climate policy compared to the focus on the regime type difference, measured by democracy quality measures. Compared to earlier research, the results indicate that the positive effect of democracy on commitment to climate cooperation depends on the realization of political rights. We find little to support the claim that democracy quality dimensions matter for climate policy outcomes. The main implication of our findings is that it could be fruitful to use more disaggregated democracy measures for the analysis of substantive research questions.
\end{abstract}

\section{Keywords}

climate change policy; democracy; democracy quality; environmental policy; measures of democracy

\section{Issue}

This article is part of the issue "Why Choice Matters: Revisiting and Comparing Measures of Democracy", edited by Heiko Giebler (WZB Berlin Social Science Center, Germany), Saskia P. Ruth (German Institute of Global and Area Studies, Germany), and Dag Tanneberg (University of Potsdam, Germany).

(C) 2018 by the authors; licensee Cogitatio (Lisbon, Portugal). This article is licensed under a Creative Commons Attribution 4.0 International License (CC BY).

\section{Introduction}

This article examines whether the analysis of the effects of specific dimensions of democracy quality, as opposed to the focus on the regime type difference, improves our understanding of cross-national variation in commitment to climate cooperation and climate change mitigation performance. Referring to the so-called Churchill hypothesis, which regards democracy as the best form of government, political scientists study the policy performance of democracies and autocracies. In answer to the political recognition of global environmental change, a growing number of studies have focused on the relation- ship between the regime type and climate change. Empirical research finds that democracies are more likely to join international environmental agreements (e.g., Bernauer, Kalbhenn, Koubi, \& Spilker, 2010; Neumayer, 2002a) and perform better in solving local and regional environmental problems that do not demand considerable behavioral changes (e.g., Bernauer \& Koubi, 2009; Li \& Reuveny, 2006; Ward, 2008; Wurster, 2013) than their autocratic counterparts (see also Fiorino, 2011, pp. $375 \mathrm{ff}$.). More recently, this conclusion has been questioned regarding global warming (e.g., Beeson, 2010; Shearman \& Smith, 2007). While quantitative research supports the relationship between democracy and the 
ratification of international climate agreements (e.g., Bättig \& Bernauer, 2009; Fredriksson \& Gaston, 2000; Gallagher \& Thacker, 2008; Neumayer, 2002a, 2002b; von Stein, 2008), the empirical literature is unclear about the relevance of regime type for climate policy outcomes (e.g., Bättig \& Bernauer, 2009; Fredriksson \& Neumayer, 2013, 2016; Gleditsch \& Sverdrup, 2002; Kneuer, 2012; Li \& Reuveny, 2006; Midlarsky, 1998; Spilker, 2012, 2013; Wurster, 2013). Wurster (2013, p. 89) argues that "it has become clear that a dichotomous distinction between democracy and autocracy is not sufficient to explain the performance results" (see also Christoff \& Eckersley, 2011, p. 439).

Previous empirical research has mainly questioned whether democracies contribute to climate protection. However, there is no consensus in the theoretical literature on how democracy influences climate policy. Different aspects of democracy are emphasized as crucial for the environment and there is no agreement on a uniform effect of the democracy quality dimensions (Burnell, 2012; Held \& Hervey, 2011; Payne, 1995). Therefore, the question is which institutional traits of democracy affect the global atmosphere (Burnell, 2012, p. 823). This issue becomes important for the measurement of democracy quality in the statistical analysis as well. In accordance with their research question, empirical studies test the effect of summary measures of democracy (e.g., from Freedom House and Polity IV) on climate policy. While several studies test the robustness of their results using multiple indicators, democracy indices vary, not only in their validity and reliability but also in their underlying democracy concept (e.g., Munck \& Verkuilen, 2002; Pickel, Stark, \& Breustedt, 2015). Moreover, results based on indices that summarize multiple democracy quality dimensions could be misleading, as their effects could balance each other out or hide the relative importance of each trait.

Our analysis contributes to the academic literature on the measurement of democracy quality. More recently, disaggregated democracy quality data for large- $\mathrm{N}$ studies has been made available by the Democracy Barometer and the Varieties of Democracy Project (V-Dem). These indicators enable us to analyze the specific mechanisms that link democracy quality to policy outputs and outcomes. Thus, we will be able to go beyond the question of whether democracy contributes or undermines policy performance, and we will be able to state which institutional traits of democracy are responsible for a better or worse policy performance. Second, we contribute to comparative climate policy research. Global warming is a worldwide environmental problem. Hence, it is fruitful to analyze the willingness and ability of governments to tackle climate change in different institutional contexts. Only a limited amount of work has been done regarding the effect of specific democracy quality dimensions on climate policy (Böhmelt, Böker, \& Ward, 2016, p. 1273). Fredriksson and Neumayer (2013, p. 18), in separate regression mod- els, find that only the historical experience of executive constraints and not the cumulative effect of competition leads to stricter climate policies. On the contrary, Wurster (2013, pp. 86f.) ascertains that there is no significant effect of checks and balances on carbon dioxide $\left(\mathrm{CO}_{2}\right)$ emissions. To our knowledge, the effects of multiple democracy quality dimensions on climate policy have not been studied simultaneously.

Our main argument is that, if democracy quality has an impact at all, it is political rights that contribute to climate protection. Since solving global warming implies considerable changes in our daily lives and economy, it depends foremost on a demand for such measures by the citizenry. Political rights together with an independent civil society enable citizens to inform themselves about global environmental change, and they enable supporters of climate change mitigation to pressure the government via the media and public opinion to address global warming. In comparison, there is little reason to believe that competitive elections alone make governments implement climate policies. The diffuse character of the climate change problem makes it unlikely that emission reductions are relevant for most citizens' decisions in elections or their organization and participation in political parties. In addition, democratic governments are presumably reluctant to adopt stricter climate policies due to the considerable short-term socio-economic costs which could affect their re-election. While checks and balances imply that more interests are considered, veto players with divergent interests are likely to hinder the adoption of stricter climate policies. Civil rights enable individuals to focus on their self-interest even if it is against the common interest of environmental protection. However, they might also contribute, via the rule of law, to the acceptance of international agreements and the implementation of climate policies.

To answer our research question, we test the effects of four democracy quality dimensions-electoral and horizontal accountability, political and civil rights-on climate policy commitment and performance using data from the V-Dem-Project (Coppedge et al., 2017; Pemstein et al., 2017). We agree with Bättig and Bernauer (2009) that it is important to distinguish between commitment and performance. Compared to climate change mitigation, participation in climate cooperation comes with little cost. With the democracy measures from Polity IV and Freedom House (Freedom House, 2017; Marshall, Gurr, \& Jaggers, 2016), we show the differences of our analytic strategy compared to former publications on the relationship between democracy and global warming. The focus on the effect of democracy quality limits the analysis to countries that have been classified as "free" or "partly-free" by Freedom House in the majority of years of our research period. Our findings shed new light on the causal mechanisms that link democracy to global warming. While results based on the Freedom House and Polity IV measures indicate that democracy quality, in general, contributes to a commitment 
to international climate cooperation, the disaggregated measurement approach shows that the positive effect of democracy on commitment to climate cooperation depends on the realization of political rights. We find limited support for the claim that the other democracy quality dimensions matter for climate policy outcomes.

In the next section (2), we summarize the theoretical discussion regarding our research question and formulate hypotheses for the empirical analysis. The dependent and independent variables are operationalized in section 3. The following section (4) conducts crosssectional analyses to explore our research question. The final section summarizes the findings and presents our conclusions (5).

\section{Institutional Traits of Democracy and Climate Policy}

In our discussion of the literature on the environmental consequences of democracy quality dimensions, we adopt the "embedded democracy" concept from Merkel (2004). Following Dahl, narrow definitions of democracy focus on competitive elections and enable the analysis of the relative performance of democracies and autocracies (e.g., Wurster, 2013, p. 82). They are less suited for the analysis of the relative importance of institutional traits of democracies for climate policy. Scholars disagree about what constitutes democracy besides competitive elections (Geissel, Kneuer, \& Lauth, 2016, p. 574). Merkel's (2004) distinction between internal and external embeddedness enables us to focus on the effects of political democracy and not on the hypotheses that link democracy to climate policy via economic development or international cooperation (Burnell, 2012; Payne, 1995). The "embedded democracy" concept distinguishes five partial regimes, namely electoral regime, political rights, civil rights, horizontal accountability, and the effective power to govern. In comparison to democracy concepts that focus on political rights and civil liberties (e.g., Collier \& Levitsky, 1997, p. 434; Freedom House, 2017), it identifies with the former four partial regimes the democracy-quality dimensions that are regarded as the most important in the democracy-environment literature. Our robustness analyses also control for three indicators regarding the effective power to govern (see Annex). With regard to the number of democracy quality dimensions the embedded democracy concept is relatively parsimonious (e.g. Diamond \& Morlino, 2005, p. xii).

Several scholars expect that electoral accountability, i.e. the right to participate in the free and fair election of political authorities (Merkel, 2004, p. 42), contributes to environmental commitment and protection. First, democratically elected governments are responsive to their citizens' policy preferences (Barrett \& Graddy, 2000; Congleton, 1992). The median voter should be more willing to accept stricter environmental regulations since they imply lower costs for citizens, compared to political and economic elites that possess a larger part of the national income (Bernauer \& Koubi, 2009, p. 1356; Congleton, 1992, pp. 416f., 421; Winslow, 2007, p. 772). Additionally, non-elected governments might not adopt long-term environmental policies since their power is uncertain (Congleton, 1992, p. 417). Second, democracies presumably provide more environmental public goods to stay in power (Bueno De Mesquita, Smith, Siverson, \& Morrow, 2003) since the price of public good provision relative to private goods falls with the size of the winning coalition (Cao \& Ward, 2015, p. 265). Finally, Fredriksson, Neumayer, Damania and Gates (2005, p. 350), List and Sturm (2006, p. 1259) and Wilson and Damania (2005) emphasize the importance of competitive elections. Governments would only consider citizens' policy preferences if their participation made a difference.

The underlying assumption that citizens are climatefriendly is questionable (Spilker, 2013; Ward, 2008, p. 389). Empirical research finds that climate concern varies among countries (e.g., Kim \& Wolinsky-Nahmias, 2014). Moreover, democratic governments are accountable to citizens within the nation-state and therefore might not be willing to deal with global environmental pollution (Held \& Hervey, 2011, p. 90). Additionally, global warming mainly affects future generations and climate policies will only impact emissions in the long-term (Bernauer \& Koubi, 2009, p. 1357; Cao \& Ward, 2015, p. 271; Wurster, 2011, pp. 546f., 2013, p. 90). The diffuse character of the climate problem makes it unlikely that emissions are relevant for most citizens' decisions in elections. Democratic governments might also face citizens who are unwilling to accept the socio-economic costs of climate change mitigation (Holden, 2002, p. 10) and, therefore, prioritize economic development (Shearman \& Smith, 2007, pp. xivf., 83). Non-elected governments also might not pursue climate-friendly policies; their legitimacy rests on their socio-economic performance. In sum, we expect that competitive elections cannot explain cross-national variation in commitment to climate cooperation (Hypothesis 1a) and climate change mitigation (Hypothesis 1b). It depends on whether supporters or opponents of climate protection are elected (see also Wurster, Auber, Metzler, \& Rohm, 2015, pp. 183f.).

In democracies, horizontal accountability (i.e. checks and balances) makes it more likely that alternative policy choices are discussed and that the public is informed about environmental policies and their implementation (Burnell, 2012, p. 823; Held \& Hervey, 2011; Wurster, 2013 , p. 83). In comparison, the environmentalist authoritarian literature emphasizes that the democratic decision-making process hinders fast action to tackle climate change. Democratic governments must find an agreement with veto players with divergent economic interests (Beeson, 2010, p. 289; Fliegauf \& Sanga, 2010, p. 2; Giley, 2012, p. 289; Wurster, 2011, p. 547, 2013, p. 79). Empirical research finds no clear support that institutional constraints contribute to or impede climate protection (e.g., Fredriksson \& Neumayer, 2013; Garman, 2014; Madden, 2014; Wurster, 2013). Overall, we believe 
that the positive and negative effects of horizontal accountability balance each other out and assume no effect of horizontal accountability on cross-national variation on climate policy commitment and performance (Hypotheses $2 \mathrm{a}$ and $2 \mathrm{~b}$ ).

In the 1970s, green political theorists argued that civil rights, i.e. constitutional rights that protect the individual against the state (Merkel, 2004, p. 39), contribute to individuals following their self-interest versus the common interest of environmental protection (e.g., Hardin, 1968; Ophuls, 1977, pp. 145ff.). However, this argument depends on the climate policy preferences of citizens. In addition, the effectiveness of using repression to enforce environmental policies is limited (Stehr, 2015, p. 450; Wurster, 2013, p. 80). Civil rights enable citizens to demand the implementation of climate policies via the courts (Spilker, 2013, pp. 55, 59; Winslow, 2007, p. 772). However, this possibility depends on existing environmental regulations. In sum, we expect that civil rights do not explain country-differences in climate policy commitment and performance (Hypotheses 3a and 3b).

Many social scientists link democracy to environmental protection via political rights, i.e. freedoms of expression, association, and the media, and the autonomy of the civil society (Merkel, 2004, p. 39). These institutional traits enable citizens to inform themselves regarding pollution (Barrett \& Graddy, 2000; Bernauer, Böhmelt, \& Koubi, 2013; p. 93f.; Payne, 1995, p. 43), to express their environmental policy-preferences (Bernauer et al., 2013, p. 93), to form environmental interest groups (ENGOs), to mobilize public support (Fredriksson \& Neumayer, 2013, p. 12; Gleditsch \& Sverdrup, 2002, p. 48), and to influence the government's decisions (Burnell, 2009, p. 6; Payne, 1995, p. 43). An independent civil society makes it more likely that citizens express their policy-preferences (Böhmelt et al., 2016, p. 1277). Free media enables citizens, journalists, and scientists to monitor government policy (Payne, 1995, p. 45) and support technological innovation as well as the spread of scientific knowledge (Gleditsch \& Sverdrup, 2002, p. 47). However, powerful special interest groups may block environmental policy reforms (e.g., Bernauer \& Koubi, 2009, p. 1357; Never \& Betz, 2014, p. 12; Shearman \& Smith, 2007, pp. 89, 91) or undermine their implementation (Midlarsky, 1998, p. 344). We expect that countries with higher levels of political rights are more committed to climate cooperation (Hypothesis 4a). Since the reduction of greenhouse gas emissions is associated with considerable short-term costs for society and economy, climate change mitigation is dependent on public awareness of global warming and support for climate protection. Democratic freedoms ensure that diffuse interests such as climate protection are at least considered as part of the political process. It is presumably more difficult for the public to control climate change mitigation compared to the ratification of climate treaties (Cao \& Prakash, 2012). Thus, we expect no effect of political rights on climate policy outcomes (Hypotheses 4b).
To conclude, if democracy quality has an impact at all, it is political rights that contribute to commitment to climate cooperation. A uniform effect of the democracy quality dimensions on climate policy outputs and outcomes cannot be expected. Hence, they should be tested separately.

\section{Research Design}

To answer our research question, we examine the relevance of democratic institutional traits using crosssectional OLS regression based on country averages from 1990-2005/2010. This is because, firstly, cross-country variations are of primary interest in this analysis. Secondly, institutional traits of democracy are relatively stable over time. Finally, we assume that political institutions affect climate policy only in the long-term. The selected period is relevant as climate change has only been recognized at the end of the last century on the international level as a global environmental problem. As our focus lies on democracy quality, we examine 99 countries that have been classified by Freedom House as "free" or "partly free" during most years of our research period. Before we present the results, this section describes the measurement of the dependent and independent variables.

\subsection{Measurement of the Dependent Variables}

Following previous research, we examine climate cooperation commitment and state efforts to mitigate global warming separately. Our indicator for commitment is the climate policy output component from the climate cooperation index created by Bättig, Brander and Imboden (2008); taken from Bättig and Bernauer (2009). It summarizes information on state behavior within the climate change regime (ratification and ratification delay of the UNFCCC and the Kyoto Protocol, reporting and reporting delay, and timely financial contributions to the UNFCCC core budget) from 1990-2005. It varies from 0-1, where higher values imply more cooperative state behavior. Because $\mathrm{CO}_{2}$ is the most important greenhouse gas, $\mathrm{CO}_{2}$ emissions per capita can be used to measure climate policy outcomes. The data is taken from the online database of the World Bank World Development Indicators (WDI) (data access in 2017). Following previous studies, we examine pollution levels. Our appendix also studies longterm and short-term changes in $\mathrm{CO}_{2}$ emissions per capita using cross-sectional and time-series cross-sectional regression analysis.

\subsection{Measurement of the Independent Variables}

In comparison to earlier research on the relationship between democracy and climate policy, we measure the effect of the democracy quality dimensions side-by-side in one regression model. Following our theoretical discussion, it is important to assess the influence of the 
democracy attributes separately. Several studies apply multiple democracy measures with different underlying democracy conceptions in separate regression models (e.g., Midlarsky, 1998; Neumayer, 2002a). However, the democracy quality dimensions should be tested simultaneously. Specific democracy quality indicators might only show a significant effect because they are highly correlated with the other institutional traits.

The effects of the democracy quality dimensions are captured by indicators developed by Lührmann, Marquardt and Mechkova (2017) and the V-Dem project (Coppedge et al., 2017; Pemstein et al., 2017). All indicators are based on expert evaluations. Our indicator of electoral accountability is the "Vertical Accountability Index" of Lührmann et al. (2017, pp. 11ff.). This index focuses on the mechanisms of formal political participation via elections and political parties in the exercise of accountability. It summarizes indicators of the quality of free and fair elections, the percentage of the population that is enfranchised, whether the chief executive is elected, and whether there is the right to organize and participate in political parties. The latter aspect enables us to consider the assumption that competitive elections are crucial. Checks and balances are captured by the "Horizontal Accountability Index" (Lührmann et al., 2017, p. 13), which represents the extent to which state institutions are able to hold the executive branch of the government to account. Three institutions are considered in this regard: the legislature, the judiciary, and special bodies designed for this purpose (e.g., ombudsman). We use the "Equality before the law and individual liberty Index" from V-Dem to measure the democratic subdimension of civil rights. This index captures the extent to which laws are transparent and rigorously enforced, and whether the public administration is impartial, the extent to which citizens enjoy access to justice, the ability to secure property rights, freedom from forced labor, freedom of movement, physical integrity rights, as well as freedom of religion. Finally, for the operationalization of political rights, we apply the "Diagonal Accountability Index" (Lührmann et al., 2017, p. 15), which captures the extent to which citizens are able to hold a government accountable outside of formal political participation. It summarizes information on media freedom, civil society characteristics, freedom of expression, and the degree to which citizens are engaged in politics.

These variables enable us to measure the dimensions of democracy quality separately and test their effects on climate policy simultaneously. In comparison to the disaggregated data from Freedom House and Polity IV, they are more valid and reliable. Both Freedom House measures and the polity2 index have validity and reliability problems with regard to conceptualization, measurement, and aggregation (e.g., Munck \& Verkuilen, 2002). In contrast to the indicators from the Democracy Barometer, our variables are not based on policy output and outcome indicators. Finally, in comparison to data from the Bertelsmann Stiftung's Transformation Index, the Democracy Barometer, and Freedom House, the VDem indicators cover our country sample and the whole research period we are interested in. We compare the disaggregated measurement approach to the Freedom House (2017) political rights and civil liberties indices and the polity2 indicator from Polity IV (Marshall et al., 2016). They have been used in most studies of democracy and climate policy. The Freedom House indicators are rescaled so that higher values on the measures from Freedom House and Polity IV indicate higher levels of democracy quality.

Our statistical analyses control for additional variables that have been applied in similar studies. Population density is included as it is associated with natural resource use (Spilker, 2012). Since emissions result mainly from economic activities, we consider the level of economic development (GDP per capita) and economic growth (GDP growth). Countries that export fossil fuels should be less likely to participate in climate cooperation and mitigate global warming. Thus, we control for the percentage of merchandise exports that are fossil fuel exports. The effect of international trade is theoretically ambiguous. Our indicator is the percentage of the sum of exports and imports of a country's GDP. Data on our socio-economic variables come from the WDI online database (data accessed in 2017). Recent research suggests that state involvement in international governmental organizations (IGOs) increases a country's willingness and ability to reduce pollution (e.g., Spilker, 2012). Data on country memberships in IGOs comes from Pevehouse, Nordstrom and Warnke (2010). On the domestic level, ENGOs pressure governments to consider environmental issues. ENGO strength is captured by data from Bernauer et al. (2013) on the number of ENGOs registered in a country with the International Union for Conservation of Nature. We consider a country's vulnerability to the consequences of global warming with the climate change index from Bättig, Wild and Imboden (2007) in Bättig and Bernauer (2009). It covers climate variability due to global warming in comparison to natural developments on a scale from $0-1$. Higher values indicate higher climate variability. More vulnerable countries should be more active in this policy area (Sprinz \& Vaahtoranta, 1994).

The climate policy outcome models test, following EKC-theory (Grossman \& Krueger, 1995), a curvilinear effect of GDP per capita. We used the mean-centered variable GDP per capita to avoid problems with non-essential multicollinearity. Our commitment indicator is also included as an independent variable. ${ }^{1}$ Countries that are more committed to climate cooperation might be more willing to reduce emissions (Bättig \& Bernauer, 2009). Table 1 summarizes the descriptive statistics of all variables included in the statistical analyses.

\footnotetext{
${ }^{1}$ To acknowledge the endogeneity of commitment to climate cooperation with regard to the explanatory variables, we also examined the climate policy outcome models with the residuals of the commitment model. The results of our climate policy outcome models stay stable.
} 
Table 1. Descriptive statistics.

\begin{tabular}{|c|c|c|c|c|}
\hline Variable & Mean & Std. Dev. & Min & Max \\
\hline Commitment to climate cooperation & .680 & .156 & .226 & .978 \\
\hline $\mathrm{CO}_{2}$ emissions per capita & 4.712 & 5.271 & .063 & 28.284 \\
\hline Electoral accountability & .975 & .479 & .031 & 1.854 \\
\hline Horizontal accountability & .799 & .752 & -.655 & 2.254 \\
\hline Political rights & 1.106 & .573 & -.253 & 2.106 \\
\hline Civil rights & .786 & .177 & .358 & .995 \\
\hline Freedom House Political rights & 5.340 & 1.428 & 2.315 & 7.000 \\
\hline Freedom House Civil liberties & 5.032 & 1.240 & 2.375 & 7.000 \\
\hline Polity2 & 5.830 & 4.409 & -7.133 & 10.000 \\
\hline Population density & 172.413 & 595.542 & 1.557 & $5,861.425$ \\
\hline GDP per capita & 13143.732 & 16979.596 & 270.110 & 78793.39 \\
\hline GDP growth & 3.453 & 1.619 & -1.786 & 7.553 \\
\hline Fuel exports & 11.567 & 20.972 & .002 & 95.484 \\
\hline Trade openness & 75.843 & 42.91 & 21.977 & 359.634 \\
\hline Memberships in IGOs & 67.909 & 19.113 & 33.933 & 123.313 \\
\hline ENGO strength & 5.818 & 7.790 & .000 & 51.444 \\
\hline Climate change vulnerability & .489 & .136 & .261 & .897 \\
\hline
\end{tabular}

Notes: $\mathrm{N}=99$. The units of analysis are country averages from 1990-2010, except commitment to climate cooperation (1990-2005), IGO membership (1990-2005) and vulnerability (1990-2005).

\section{Results}

\subsection{Commitment to Climate Cooperation}

Table 2 presents the results of our first dependent variable commitment to climate cooperation from 19902005. Positive skewness of variables is reduced using the natural logarithm (In). Tolerance values of our regression models indicate no problems with multicollinearity. Our results remain stable if we apply robust standard errors. Regarding the control variables, our models show that trade openness contributes to commitment. $R^{2}$ values increase considerably when we exclude outliers (see Annex). While nearly all democracy aspects are associated with higher levels of climate policy commitment, only the effect of political rights is significant. Electoral accountability is negatively but insignificantly associated with commitment. This supports our hypotheses $1 \mathrm{a}, 2 \mathrm{a}$ and $3 a$ that electoral and horizontal, as well as civil rights cannot explain country-differences in commitment to climate cooperation. In accordance with hypothesis 4 a, we find that countries with high levels of political rights are also more committed.

Models 2-4 in Table 2 show that both Freedom House indicators and the polity 2 indicator have a positive and significant effect on commitment. If the democracy quality dimensions are examined in separate models, each contributes significantly to commitment as well (see Annex). Thus, the summary measures exhibit significant positive effects as they either encompass political rights indicators or are highly correlated with political rights.
We performed several robustness analyses (see Annex). Testing cumulative effects of the democracy quality dimensions (Fredriksson \& Neumayer, 2013; Gallagher \& Thacker, 2008) from 1950-2005/2010, we yield the same conclusions. Our results also remain stable if we control for the Annex-I status and the level of $\mathrm{CO}_{2}$ emissions per capita. If we add countries classified as "not free" for most years from 1990-2010, the positive effect of political rights on commitment is also significant. The results of the commitment model remain stable if we estimate our models without outliers and if we exclude developed countries or countries from a particular region.

Following our theoretical expectations, political rights might contribute to commitment since they enable citizens and interest groups to pressure the government to consider climate change. However, we find no significant interaction effect between political rights and ENGO influence (see Annex). This finding might result from our indicator of the political influence of ENGOs which just counts the number of domestic ENGOs. In addition, many domestic ENGOs focus on local environmental problems (Never \& Betz, 2014, p. 12).

\subsection{Climate Change Mitigation}

Table 3 summarizes the results for average $\mathrm{CO}_{2}$ emissions per capita levels (In) from 1990-2010. In our models, population density, fuel exports and, contrary to our expectations, ENGO strength contribute to emissions. In accordance with EKC-research, we find an inverse $U$ shaped relationship between GDP per capita and $\mathrm{CO}_{2}$ emissions per capita. The findings support that growth, 
Table 2. Democracy quality dimensions and climate cooperation commitment (OLS regression analysis).

\begin{tabular}{|c|c|c|c|c|}
\hline & (1) & $(2)$ & (3) & (4) \\
\hline Population density (In) & $\begin{array}{l}.008 \\
(.010)\end{array}$ & $\begin{array}{c}.004 \\
(.009)\end{array}$ & $\begin{array}{c}.013 \\
(.009)\end{array}$ & $\begin{array}{l}.000 \\
(.010)\end{array}$ \\
\hline GDP per capita (In) & $\begin{array}{c}-.002 \\
(.016)\end{array}$ & $\begin{array}{c}-.005 \\
(.014)\end{array}$ & $\begin{array}{c}-.017 \\
(.014)\end{array}$ & $\begin{array}{l}.015 \\
(.014)\end{array}$ \\
\hline GDP growth & $\begin{array}{c}.006 \\
(0.007)\end{array}$ & $\begin{array}{c}.006 \\
(.007)\end{array}$ & $\begin{array}{c}.006 \\
(.007)\end{array}$ & $\begin{array}{l}.010 \\
(.007)\end{array}$ \\
\hline Fuel exports (In) & $\begin{array}{l}-.008 \\
(.012)\end{array}$ & $\begin{array}{l}-.005 \\
(.012)\end{array}$ & $\begin{array}{l}.002 \\
(.011)\end{array}$ & $\begin{array}{l}-.012 \\
(.012)\end{array}$ \\
\hline Trade openness (In) & $\begin{array}{l}.091 * * \\
(.035)\end{array}$ & $\begin{array}{l}.078^{* *} \\
(.033)\end{array}$ & $\begin{array}{l}.058^{*} \\
(.032)\end{array}$ & $\begin{array}{l}.072 * * \\
(.035)\end{array}$ \\
\hline Memberships in IGOs & $\begin{array}{l}.000 \\
(.001)\end{array}$ & $\begin{array}{c}.001 \\
(0.001)\end{array}$ & $\begin{array}{l}.000 \\
(.001)\end{array}$ & $\begin{array}{c}.001 \\
(0.001)\end{array}$ \\
\hline ENGO strength (In) & $\begin{array}{l}.036 * \\
(.021)\end{array}$ & $\begin{array}{c}.021 \\
(.020)\end{array}$ & $\begin{array}{l}.027 \\
(.019)\end{array}$ & $\begin{array}{c}.020 \\
(.022)\end{array}$ \\
\hline Climate change vulnerability & $\begin{array}{l}-.028 \\
(.099)\end{array}$ & $\begin{array}{l}-.073 \\
(.095)\end{array}$ & $\begin{array}{l}-.027 \\
(.091)\end{array}$ & $\begin{array}{l}-.116 \\
(.100)\end{array}$ \\
\hline Electoral accountability & $\begin{array}{l}-.009 \\
(.060)\end{array}$ & & & \\
\hline Horizontal accountability & $\begin{array}{l}.010 \\
(.031)\end{array}$ & & & \\
\hline Political rights & $\begin{array}{l}.106^{* *} \\
(.049)\end{array}$ & & & \\
\hline Civil rights & $\begin{array}{l}.138 \\
(.158)\end{array}$ & & & \\
\hline $\begin{array}{l}\text { Freedom House Political rights } \\
\text { Freedom House Civil liberties }\end{array}$ & & $\begin{array}{l}.061^{* * *} \\
(.013)\end{array}$ & $\begin{array}{l}.093^{* * *} \\
(.016)\end{array}$ & \\
\hline Polity2 & & & & $\begin{array}{l}.013^{* * *} \\
(.004)\end{array}$ \\
\hline $\begin{array}{l}\text { Countries } \\
\mathrm{R}^{2}\end{array}$ & $\begin{array}{l}99 \\
.452\end{array}$ & $\begin{array}{l}99 \\
.451\end{array}$ & $\begin{array}{r}99 \\
.503\end{array}$ & $\begin{array}{r}99 \\
.391\end{array}$ \\
\hline
\end{tabular}

Notes: Unstandardized regression coefficients and standard errors in parentheses. ${ }^{* * *} p<.01,{ }^{* *} p<.05,{ }^{*} p<.10$. The units of analysis are country averages from 1990-2005.

country memberships in IGOs as well as vulnerability are associated with lower emissions levels.

Moreover, the analysis indicates that cross-national variation in the democracy quality dimensions does not explain country-differences in climate policy outcomes. In accordance with our theoretical expectations (hypotheses $1 b, 2 b, 3 b$ and $4 b$ ), we find no effect of vertical and horizontal accountability as well as civil and political rights on cross-national variation in $\mathrm{CO}_{2}$ emissions. However, while political rights and horizontal accountability are negatively associated with emission levels, electoral accountability and civil rights show positive effects. Both Freedom House indicators and the polity2 indicator are not associated with emission levels.

Our results remain stable if we exclude developed countries (see Annex). We also examined the effects of the democracy quality dimensions on average $\mathrm{CO}_{2}$ emissions in two sub-periods (1990-1999, 2000-2010). In contrast to our theoretical expectations, we find a signif- icant positive effect of electoral accountability on average $\mathrm{CO}_{2}$ emissions per capita from 1990-1999, if we exclude countries from the Middle East and North Africa. However, many countries might not have adopted mitigation measures in the early years of the international climate change regime. Additionally, the time it takes for climate policies to affect greenhouse gas emissions has to be considered. The robustness analyses suggest no effect of the democracy quality dimensions on short-term and long-term changes in $\mathrm{CO}_{2}$ emissions per capita.

It appears that the cross-national variance in political rights explains commitment to climate cooperation better than country-differences in vertical accountability, horizontal accountability and civil rights. Our results are based on correlations. Case studies could give us more insight into the causal processes that link political rights to commitment to international efforts to tackle climate change. In the following, we examine Ecuador in more detail, a country that performs well with re- 
Table 3. Democracy quality dimensions and $\mathrm{CO}_{2}$ emissions per capita, In (OLS regression analysis).

\begin{tabular}{|c|c|c|c|c|}
\hline & (1) & $(2)$ & (3) & (4) \\
\hline Population density (In) & $\begin{array}{l}.087^{* *} \\
(.039)\end{array}$ & $\begin{array}{l}.093^{* *} \\
(.038)\end{array}$ & $\begin{array}{l}.089 * * \\
(.040)\end{array}$ & $\begin{array}{l}.092 * * \\
(.038)\end{array}$ \\
\hline GDP per capita (In) & $\begin{array}{l}.856^{* * *} \\
(.069)\end{array}$ & $\begin{array}{l}.897^{* * *} \\
(.061)\end{array}$ & $\begin{array}{l}.911^{* * *} \\
(.063)\end{array}$ & $\begin{array}{l}.900 * * * \\
(.054)\end{array}$ \\
\hline GDP per capita $(\ln )$ squared & $\begin{array}{l}-.128 * * * \\
(.028)\end{array}$ & $\begin{array}{l}-.135^{* * *} \\
(.026)\end{array}$ & $\begin{array}{l}-.135^{* * *} \\
(.026)\end{array}$ & $\begin{array}{l}-.133^{* * *} \\
(.027)\end{array}$ \\
\hline GDP growth & $\begin{array}{c}-.092^{* *} \\
(.035)\end{array}$ & $\begin{array}{c}-.080 * * \\
(.034)\end{array}$ & $\begin{array}{c}-.080 * * \\
(.034)\end{array}$ & $\begin{array}{c}-.077^{* *} \\
(.035)\end{array}$ \\
\hline Fuel exports (In) & $\begin{array}{l}.249 * * * \\
(.051)\end{array}$ & $\begin{array}{l}.235^{* * *} \\
(.148)\end{array}$ & $\begin{array}{l}.229 * * * \\
(.051)\end{array}$ & $\begin{array}{l}.235^{* * *} \\
(.050)\end{array}$ \\
\hline Trade openness (In) & $\begin{array}{c}.077 \\
(0.157)\end{array}$ & $\begin{array}{l}.104 \\
(.004)\end{array}$ & $\begin{array}{l}.096 \\
(.146)\end{array}$ & $\begin{array}{l}.102 \\
(.147)\end{array}$ \\
\hline Memberships in IGOs & $\begin{array}{l}-.014^{* * *} \\
(.004)\end{array}$ & $\begin{array}{l}-.014^{* * *} \\
(.004)\end{array}$ & $\begin{array}{l}-.013^{* * *} \\
(.004)\end{array}$ & $\begin{array}{l}-.014 * * * \\
(.004)\end{array}$ \\
\hline ENGO strength (In) & $\begin{array}{c}.142 \\
(.086)\end{array}$ & $\begin{array}{l}.152^{*} \\
(.085)\end{array}$ & $\begin{array}{c}.153^{*} \\
(.085)\end{array}$ & $\begin{array}{l}.149 * \\
(.086)\end{array}$ \\
\hline Climate change vulnerability & $\begin{array}{c}-1.222^{* * *} \\
(.419)\end{array}$ & $\begin{array}{c}-1.218^{* * *} \\
(.570)\end{array}$ & $\begin{array}{c}-1.237^{* * *} \\
(.417)\end{array}$ & $\begin{array}{c}-1.221^{* *} \\
(.412)\end{array}$ \\
\hline Commitment to climate cooperation & $\begin{array}{c}.535 \\
(.438)\end{array}$ & $\begin{array}{l}.467 \\
(.437)\end{array}$ & $\begin{array}{c}.555 \\
(.456)\end{array}$ & $\begin{array}{c}.465 \\
(.418)\end{array}$ \\
\hline Electoral accountability & $\begin{array}{c}.347 \\
(.268)\end{array}$ & & & \\
\hline Horizontal accountability & $\begin{array}{c}-.034 \\
(.136)\end{array}$ & & & \\
\hline Political rights & $\begin{array}{c}-.248 \\
(.212)\end{array}$ & & & \\
\hline Civil rights & $\begin{array}{c}.391 \\
(0.675)\end{array}$ & & & \\
\hline Freedom House Political rights & & $\begin{array}{c}.017 \\
(.060)\end{array}$ & & \\
\hline Freedom House Civil liberties & & & $\begin{array}{c}-.011 \\
(.081)\end{array}$ & \\
\hline Polity2 & & & & $\begin{array}{c}.007 \\
(0.017)\end{array}$ \\
\hline $\begin{array}{l}\text { Countries } \\
\mathrm{R}^{2}\end{array}$ & $\begin{array}{l}99 \\
.917\end{array}$ & $\begin{array}{l}99 \\
.915\end{array}$ & $\begin{array}{l}99 \\
.915\end{array}$ & $\begin{array}{l}99 \\
.915\end{array}$ \\
\hline
\end{tabular}

Notes: Unstandardized regression coefficients and standard errors in parentheses. ${ }^{* * *} p<.01,{ }^{* *} p<.05,{ }^{*} p<.10$. The units of analysis are country averages of from 1990-2010. IGO membership, ENGO strength and commitment refer to country averages from 1990 to 2005 .

gard to political rights and commitment to climate cooperation but has deficits in another democracy quality dimension (horizontal accountability). ${ }^{2}$ Simultaneously, Ecuador performs above-average on our measure of climate cooperation commitment. The political system of Ecuador is characterized by free and fair elections and the respect of civil rights. Ecuador shows deficits with regard to horizontal accountability during our research period. The independence of the judiciary in Ecuador is restricted. The executive and the legislative branches of government have repeatedly influenced court decisions for their benefit. In comparison, there are no re- strictions on the freedoms of association, expression, or the press. Ecuador has above average values on our political rights indicator. Since the 1990s, civil society organizations representing indigenous people have gained in influence in the Ecuadorian political system. They have also been organized around environmental issues such as the ecological consequences of petroleum extraction in the Amazon lowlands. Case studies have shown that the Ecuadorian government's international climate policy has been influenced by civil society organizations (e.g. Espinosa, 2013; Martin, 2011). In the mid-1990s domestic NGOs, scientists and indigenous groups de-

\footnotetext{
${ }^{2}$ We use information from the country reports of the Bertelsmann Stiftung's Transformation Index from 2003 and 2006.
} 
manded a halt to oil drilling in the Ecuadorian Amazon. Espinosa (2013) argues that the environmental interests groups were able to change the public discourse on petroleum extraction in the oil exporting country. The government of President Correa was responsive to the influence of civil society organizations (Martin, 2011, pp. 26f.). It worked together with domestic NGOs to formulate a proposal to the international community (Martin, 2011, pp. 31f., 39). The Ecuadorian government finally proposed that it would commit itself to not extracting the country's largest oil reserves in the Yasuní National Park in the Amazon and thus avoid considerable greenhouse gas emissions under the condition that it would receive international financial compensation (Martin, 2011, p. 22). Martin (2011, p. 31) concludes that the Ecuadorian government represented the climate policy position of the civil society organizations on the international level. The example of Ecuador shows that political rights enabled civil society to influence the country's climate policy (Martin, 2011, pp. 27f.). This case also illustrates the difference between climate policy commitment and climate change mitigation. The Ecuadorian government introduced the condition of financial compensation. It was, in the end, unwilling to stop oil drilling in the Yasuní National Park since there was little financial support from the international community. With regard to commitment to climate policy goals, states appear to be responsive to the climate policy demands of citizens and civil society organizations facilitated by political rights although they are more reluctant to implement climate change mitigation policies.

\section{Discussion and Conclusion}

Our results show that the conceptualization and measurement of democracy matters in comparative climate policy research. With the measures from Freedom House and Polity IV, we observe positive effects on climate policy commitment. In comparison, the disaggregated measurement approach indicates that only the realization of political rights is crucial. The results suggest that previous research might have only found significant effects of democracy quality measures on commitment because they contain or are highly correlated with the dimension of political rights. This finding sheds new light on the causal mechanisms that link democracy to commitment. In accordance with our theoretical expectations, we find that the positive effect of democracy quality depends on political rights. It appears that electoral and horizontal accountability, as well as civil rights, are not decisive for country-differences in commitment to climate cooperation. The effect of competitive elections depends on the electoral success of supporters and opponents of climate protection. Horizontal accountability provides incentives and constraints to participation in climate cooperation. The effect of civil rights depends on a country's existing climate policy regulations. We do not believe that political rights alone contribute to climate cooperation either. Climate change mitigation is dependent on public awareness of global warming and support for climate protection. For instance, Harrison and Sundstrom (2010) conclude from their case studies of Kyoto Protocol ratification that the EU member states and Japan were able to ratify the agreement since public and business interests supported it. In comparison, Australia withdrew its ratification and the United States never ratified it since public climate concern was low and industry interest groups opposed ratification. Our argument is that political rights enable supporters of climate change mitigation to raise awareness of climate change, articulate their climate policy preferences, and mobilize public support in the first place. These democratic freedoms make it, therefore, more likely that diffuse interests such as climate protection are considered in the political process (see also Martin, 2011). For instance, Never and Betz $(2014$, p. 12) demonstrate that civil society organizations had no influence on climate policy in India and South Africa since they had no access to the domestic political decision-making process. In accordance with our theoretical expectations and earlier research, we find little support for the claim that democracy quality or the democracy quality dimensions-electoral and horizontal accountability, political and civil rights-matter for climate policy outcomes. If at all, electoral accountability may have been associated with higher emission levels in the 1990s. While political rights contribute to commitment to climate cooperation, they are not associated with lower emission levels. An explanation for this finding is that it is, presumably, more difficult for the public to control the implementation of environmental policies (Cao \& Prakash, 2012).

The main implication of our results for the analysis of substantive research questions in empirical democracy research is that it could be fruitful to study the implications of democracy on a disaggregated basis to gain more analytical clarity and, therefore, to conceptualize and measure democracy quality dimensions separately. Further climate policy research could investigate the relationship between political rights and global warming policy in more detail. Our study has focused on institutional traits. To gain more knowledge on the effect of political rights on climate cooperation, more attention should also be given to the policy-preferences of political decision-makers and citizens and their interaction with political rights. It would also be interesting to examine the relative importance of political rights such as freedom of expression, freedom of association, and civil society autonomy for climate policy. We also have not considered elements of direct democracy.

\section{Acknowledgments}

The authors would like to thank the editors of the special issue, Heiko Giebler, Saskia Ruth and Dag Tanneberg, and the two anonymous reviewers for their helpful comments. This article has benefited also from the valuable 
comments and suggestions of Dieter Fuchs, Brigitte Geissel, Hans-Joachim Lauth, Quinton Mayne, Elena Rinklef, Gary S. Schaal, Oliver Schlenkrich, Sebastian Stier and Stefan Wurster on previous versions of this manuscript. This work was supported by the German Research Foundation (DFG) within the funding programme Open Access Publishing.

\section{Conflict of Interests}

The authors declare no conflict of interests.

\section{References}

Barrett, S., \& Graddy, K. (2000). Freedom, growth, and the environment. Environment and Development Economics, 5, 433-456.

Bättig, M. B., \& Bernauer, T. (2009). National institutions and global public goods. Are democracies more cooperative in climate change policy? International Organization, 63(2), 281-308.

Bättig, M. B., Brander, S., \& Imboden, D. (2008). Measuring countries' cooperation within the international climate change regime. Environmental Science \& Policy, 11, 478-489.

Bättig, M. B., Wild, M., \& Imboden, D. (2007). A climate change index. Where climate change may be most prominent in the 21st century. Geophysical Research Letters, 34(1), 1-6.

Beeson, M. (2010). The coming of environmental authoritarianism. Environmental Politics, 19(2), 276-294.

Bernauer, T., Böhmelt, T., \& Koubi, V. (2013). Is there a democracy-civil society paradox in global environmental governance? Global Environmental Politics, 13(1), 88-107.

Bernauer, T., Kalbhenn, A., Koubi, V., \& Spilker, G. (2010). A comparison of international and domestic sources of global governance dynamics. British Journal of Political Science, 40, 509-538.

Bernauer, T., \& Koubi, V. (2009). Effects of political institutions on air quality. Ecological Economics, 68, 1355-1365.

Böhmelt, T., Böker, M., \& Ward, H. (2016). Democratic inclusiveness, climate policy outputs, and climate policy outcomes. Democratization, 23(7), 1272-1291.

Bueno De Mesquita, B., Smith, A., Siverson, R. M., \& Morrow, J. D. (2003). The logic of political survival. Cambridge, MA and London: MIT Press.

Burnell, P. (2009). Is democratization bad for global warming? (CSGR Working Paper no. 257). Warwick: University of Warwick.

Burnell, P. (2012). Democracy, democratization and climate change. Complex relationships. Democratization, 19(5), 813-842.

Cao, X., \& Prakash, A. (2012). Trade competition and environmental regulations: Domestic political constraints and issue visibility. The Journal of Politics, 74(1), 66-82.
Cao, X., \& Ward, H. (2015). Winning coalition size, state capacity, and time horizons. An application of modified selectorate theory to environmental public goods provision. International Studies Quarterly, 59, 264-279.

Christoff, P., \& Eckersley, R. (2011). Comparing state responses. In J. S. Dyrzek, R. B. Norgaard, \& D. Schlosberg (Eds.), Oxford handbook of climate change and society (pp. 431-448). Oxford: Oxford University Press.

Collier, D., \& Levitsky, S. (1997). Democracy with adjectives. Conceptual innovation in comparative research. World Politics, 49, 430-451.

Congleton, R. D. (1992). Political institutions and pollution control. The Review of Economics and Statistics, 74(3), 412-421.

Coppedge, M., Gerring, J., Lindberg, S., Skaaning, S.E., Teorell, J., Altman, D., . . . Wilson, S. (2017). VDem [country-year/country-date] Dataset v7.1. Varieties of Democracy (V-Dem) Project. Retrieved from https://www.v-dem.net/en/data/data-version-7-1

Diamond, L., \& Morlino, L. (2005). Introduction. In L. Diamond \& L. Morlino (Eds.), Assessing the quality of democracy (pp. xi-xliii). Baltimore, MD: The John Hopkins University Press.

Espinosa, C. (2013). The riddle of leaving the oil in the soil-Ecuador's Yasuní project from a discourse perspective. Forest and Economics, 36, 27-36.

Fiorino, D. (2011). Explaining national environmental performance: Approaches, evidence, and implications. Policy Sciences, 44, 367-389.

Fliegauf, M. T., \& Sanga, S. (2010). Steering toward climate tyranny? Retrieved from http://www.eisanet.org/sitecore/content/be-bruga/eisa/publications /feeds/stockholm.aspx

Fredriksson, P. G., \& Gaston, N. (2000). Ratification of the 1992 climate change convention. What determines legislative delay? Public Choice, 104, 345-368.

Fredriksson, P. G., \& Neumayer, E. (2013). Democracy and climate change policies. Is history important? Ecological Economics, 95, 11-19.

Fredriksson, P. G., \& Neumayer, E. (2016). Corruption and climate change policies: Do the bad old days matter? Environmental and Resource Economics, 63(2), 451-469.

Fredriksson, P. G., Neumayer, E., Damania, R., \& Gates, S. (2005). Environmentalism, democracy, and pollution control. Journal of Environmental Economics and Management, 49, 343-365.

Freedom House. (2017). Freedom in the world 2017. Freedom House. Retrieved from https:// freedomhouse.org/report/freedom-world/freedomworld-2017

Gallagher, K. P., \& Thacker, S. C. (2008). Democracy, income, and environmental quality (Working Paper Series no. 164). Amherst, MA: Political Economy Research Institute (PERI).

Garman, S. (2014). Do government ideology and frag- 
mentation matter for reducing $\mathrm{CO}_{2}$-emissions? Empirical evidence from OECD countries. Ecological Economics, 105, 1-10.

Geissel, B., Kneuer, M., \& Lauth, H.-J. (2016). Measuring the quality of democracy: Introduction. International Political Science Review, 37(5), 571-579.

Giley, B. (2012). Authoritarian environmentalism and China's response to climate change. Environmental Politics, 21(2), 287-307.

Gleditsch, N. P., \& Sverdrup, B. (2002). Democracy and the environment. In E. A. Page \& M. Redclift (Eds.), Human security and the environment. International comparisons (pp. 45-70). Cheltenham and Northampton: Edward Elgar.

Grossman, G. M., \& Krueger, A. B. (1995). Economic growth and environment. Quarterly Journal of Economics, 110, 353-377.

Hardin, G. (1968). The tragedy of the commons. Science, 162, 1243-1248.

Harrison, K., \& Sundstrom, L. M. (2010). Conclusion: The comparative politics of climate change. In K. Harrison \& L. M. Sundstrom (Eds.), Global commons, domestic decisions. The comparative politics of climate change (pp. 261-290). Cambridge, MA and London: MIT Press.

Held, D., \& Hervey, A. (2011). Democracy, climate change and global governance. Democratic agency and the policy menu ahead. In D. Held, A. Fane-Hervey, \& M. Theros (Eds.), The governance of climate change. Science, economics, politics and ethics (pp. 89-110). Cambridge and Malden, MA: Polity Press.

Holden, B. (2002). Democracy and global warming. London and New York, NY: Continuum.

Kim, S. Y., \& Wolinsky-Nahmias, Y. (2014). Cross-national public opinion on climate change: The effects of affluence and vulnerability. Global Environmental Politics, 14(1), 79-106.

Kneuer, M. (2012). Who is greener? Climate action and political regimes: Trade-offs for national and international actors. Democratization, 19(5), 865-888.

Li, Q., \& Reuveny, R. (2006). Democracy and environmental degradation. International Studies Quarterly, 50, 935-956.

List, J. A., \& Sturm, D. M. (2006). How elections matter: Theory and evidence from environmental policy. The Quarterly Journal of Economics, 121(4), 1249-1281.

Lührmann, A., Marquardt, K. L., \& Mechkova, V. (2017). Constraining governments: New indices of vertical, horizontal and diagonal accountability (Working Paper Series no. 46). Gothenburg: The Varieties of Democracy Institute.

Madden, N. J. (2014). Green means stop: Veto players and their impact on climate-change policy outputs. Environmental Politics, 23(4), 570-589.

Marshall, M. G., Gurr, T. R., \& Jaggers, K. (2016). Polity IV project, political regime characteristics and transitions, 1800-2015. Center for Systemic Peace. Retrieved from http://www.systemicpeace.org/inscr data.html

Martin, P. L. (2011). Global governance from the Amazon: Leaving oil underground in Yasuní National Park, Ecuador. Global Environmental Politics, 11(4), 22-42.

Merkel, W. (2004). Embedded and defective democracies. Democratization, 11(5), 33-58.

Midlarsky, M. I. (1998). Democracy and the environment. An empirical assessment. Journal of Peace Research, 35(3), 341-361.

Munck, G. L., \& Verkuilen, J. (2002). Conceptualizing and measuring democracy. Evaluating alternative indices. Comparative Political Studies, 35(5), 5-34.

Neumayer, E. (2002a). Do democracies exhibit stronger international environmental commitment? A crosscountry analysis. Journal of Peace Research, 39(2), 139-164.

Neumayer, E. (2002b). Does trade openness promote multilateral environmental cooperation? The World Economy, 25(6), 815-832.

Never, B., \& Betz, J. (2014). Comparing the climate policy performance of emerging economies. World Development, 59, 1-15.

Ophuls, W. (1977). Ecology and the politics of scarcity. Prologue to a political theory of the steady state. San Francisco, CA: W. H. Freeman and Company.

Payne, R. A. (1995). Freedom and the environment. Journal of Democracy, 6(3), 41-55.

Pemstein, D., Marquardt, K. L., Tzelgov, E., Wang, Y., Krusell, J., \& Miri, F. (2017). The V-Dem measurement model: Latent variable analysis for cross-national and cross-temporal expert-coded data (Working Paper no. 21, 2nd ed.). Gothenburg: Varieties of Democracy Institute.

Pevehouse, J. C., Nordstrom, T., \& Warnke, K. (2010). The COW-2 international organisations dataset version 2.3. Conflict Management and Peace Science, 21, 101-119.

Pickel, S., Stark, T., \& Breustedt, W. (2015). Assessing the quality of quality measures of democracy. A theoretical framework and its empirical application. European Political Science, 14, 496-520.

Shearman, D., \& Smith, J. W. (2007). The climate change challenge and the failure of democracy. Westport, CT and London: Praeger Publishers.

Spilker, G. (2012). Helpful organisations. Membership in inter-governmental organisations and environmental quality in developing countries. British Journal of Political Science, 42(02), 345-370.

Spilker, G. (2013). Globalization, political institutions and the environment in developing countries. New York, NY and London: Routledge.

Sprinz, D., \& Vaahtoranta, T. (1994). The interest-based explanation of international environmental policy. International Organization, 48(1), 77-105.

Stehr, N. (2015). Democracy is not an inconvenience. Nature, 525(24), 449-450.

von Stein, J. (2008). The international law and politics of climate change. Ratification of the United Nations 
Framework Convention and the Kyoto Protocol. Journal on Conflict Resolution, 52(2), 243-268.

Ward, H. (2008). Liberal democracy and sustainability. Environmental Politics, 17(3), 386-409.

Wilson, J. K., \& Damania, R. (2005). Corruption, political competition and environmental policy. Journal of Environmental Economics and Management, 49, 516-535.

Winslow, M. (2007). Is democracy good for the environment? Journal of Environmental Planning and Management, 48(5), 771-783.

Wurster, S. (2011). Sustainability and regime type: Do democracies perform better in promoting sustainable development than autocracies? Zeitschrift für Staats- und Europawissenschaften, 9(4), 538-559.

Wurster, S. (2013). Comparing ecological sustainability in autocracies and democracies. Contemporary Politics, 19(1), 76-93.

Wurster, S., Auber, B., Metzler, L., \& Rohm, C. (2015). Institutionelle Voraussetzungen nachhaltiger Politikgestaltung [Institutional preconditions for sustainable policy-making]. Zeitschrift für Politik, 62(2), 177-196.

\section{About the Authors}

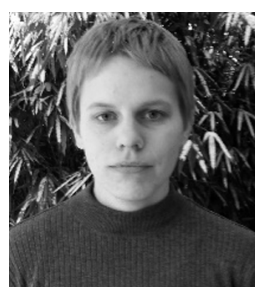

Romy Escher is a research assistant and PhD candidate at the Institute of Political Science of the University of Regensburg. Her research interests include Climate Policy, Comparative Policy Analysis, and empirical research methods.

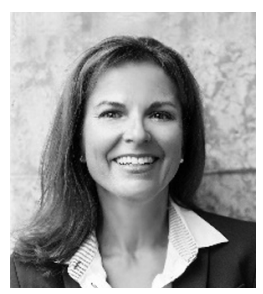

Melanie Walter-Rogg is Professor of Political Science and Methodology at the University of Regensburg. She has co-edited The Political Ecology of the Metropolis (ECPR Press, 2013) and authored a number of scholarly articles and book chapters related to Public Policy Analysis, Metropolitan Governance, Urban Democracy as well as Political Culture and Political Behaviour. 
Annex

\section{Models with Indicators of the Effective Power to Govern}

The concept of "embedded democracy" from Merkel (2004) distinguishes five interdependent partial regimes, namely electoral regime, political rights, civil rights, horizontal accountability, and the effective power to govern. Table A1 tests, also the effect of the effective power to govern. The effective power to govern means that only elected authorities participate in political decision-making processes. We considered three indicators: The Domestic Autonomy (v2svdomaut) item from the V-Dem Project (Coppedge et al., 2017; Pemstein et al., 2017) evaluates a state's autonomy in domestic politics from external actors. The variable International autonomy (v2svinlaut) from the V-Dem Project (Coppedge et al., 2017; Pemstein et al., 2017) captures a state's independence in foreign policy from external actors. The external constraints (exconst) indicator from Marshall et al. (2016) measures constraints on the government by various accountability groups (e.g., the legislature, the judiciary, the military). The results of our main analysis remain stable. In addition, we find a significant positive effect of a state's autonomy in foreign policy on commitment. In comparison, the domestic and international autonomy does not matter for $\mathrm{CO}_{2}$ emissions per capita. The exconst indicator overlaps with our measure of horizontal accountability. However, the results remain the same, when we exclude horizontal accountability.

Table A1. Effective power to govern and commitment to climate cooperation and $\mathrm{CO}_{2}$ emissions per capita, In (OLS regression analysis).

\begin{tabular}{|c|c|c|}
\hline & (2) Commitment to climate cooperation & (4) $\mathrm{CO}_{2}$ emissions per capita, In \\
\hline Population density (In) & $\begin{array}{l}.004 \\
(.009)\end{array}$ & $\begin{array}{l}-.090 * * \\
(.040)\end{array}$ \\
\hline GDP per capita (In) & $\begin{array}{l}-.007 \\
(.016)\end{array}$ & $\begin{array}{l}.862^{* * *} \\
(.071)\end{array}$ \\
\hline GDP per capita (In) squared & & $\begin{array}{l}.130 * * * \\
(.031)\end{array}$ \\
\hline GDP growth & $\begin{array}{c}.004 \\
(.007)\end{array}$ & $\begin{array}{l}-.100 * * * \\
(.035)\end{array}$ \\
\hline Fuel exports (In) & $\begin{array}{c}-.009 \\
(.012)\end{array}$ & $\begin{array}{l}.254^{* * *} \\
(.052)\end{array}$ \\
\hline Trade openness (In) & $\begin{array}{l}.097^{* * *} \\
(.035)\end{array}$ & $\begin{array}{c}.063 \\
(.162)\end{array}$ \\
\hline Memberships in IGOs & $\begin{array}{l}.000 \\
(.001)\end{array}$ & $\begin{array}{l}-.014^{* * *} \\
(.004)\end{array}$ \\
\hline ENGO strength (In) & $\begin{array}{c}.032 \\
(.021)\end{array}$ & $\begin{array}{r}.135^{*} \\
(.072)\end{array}$ \\
\hline Climate change vulnerability & $\begin{array}{l}.035 \\
(.100)\end{array}$ & $\begin{array}{c}-1.111^{* *} \\
(.435)\end{array}$ \\
\hline Commitment to climate cooperation & & $\begin{array}{c}.435 \\
(.447)\end{array}$ \\
\hline Electoral accountability & $\begin{array}{c}-.047 \\
(.063)\end{array}$ & $\begin{array}{l}.224 \\
(.281)\end{array}$ \\
\hline Horizontal accountability & $\begin{array}{l}.012 \\
(.031)\end{array}$ & $\begin{array}{c}-.034 \\
(.137)\end{array}$ \\
\hline Political rights & $\begin{array}{l}.093^{*} \\
(.049)\end{array}$ & $\begin{array}{l}-.248 \\
(.216)\end{array}$ \\
\hline Civil rights & $\begin{array}{c}.178 \\
(.157)\end{array}$ & $\begin{array}{l}.447 \\
(.684)\end{array}$ \\
\hline Domestic autonomy & $\begin{array}{c}.002 \\
(.041)\end{array}$ & $\begin{array}{c}-.162 \\
(.183)\end{array}$ \\
\hline International autonomy & $\begin{array}{l}.068^{*} \\
(.035)\end{array}$ & $\begin{array}{l}.118 \\
(.157)\end{array}$ \\
\hline External constraints & $\begin{array}{l}.005 \\
(.004)\end{array}$ & $\begin{array}{c}.034 \\
(.022)\end{array}$ \\
\hline
\end{tabular}


Table A1. Effective power to govern and commitment to climate cooperation and $\mathrm{CO}_{2}$ emissions per capita, In (OLS regression analysis). (Cont.)

(2) Commitment to climate cooperation

(4) $\mathrm{CO}_{2}$ emissions per capita, In

Countries

99

99

$\mathrm{R}^{2} \quad .500$ .921

Notes: Unstandardized regression coefficients and standard errors in parentheses. ${ }^{* *} p<.01,{ }^{* *} p<.05,{ }^{*} p<.10$. The units of analysis are country averages from 1990-2005 (Model 1) and from 1990-2010 (Model 2). IGO membership, ENGO strength and commitment refer to country averages from 1990-2005.

\section{Test of the Effect of the Democracy Quality Dimensions in Separate Regression Models}

The summary measures of democracy in our main analysis showed significant positive effects on commitment. In comparison, the separate analysis of the democracy quality dimensions found that only political rights matter for commitment. Table A2 tests the effect of the democracy quality dimensions in separate regression models. Table A2 shows that in separate regression models all democracy quality dimensions are significantly associated with commitment to climate cooperation. This result indicates that summary measures of democracy, as well as our indicators of electoral, horizontal accountability, and civil rights in Table A3, are only significantly associated with commitment as they are highly correlated with political rights.

Table A3 examines the effect of the democracy quality dimensions on $\mathrm{CO}_{2}$ emissions levels in separate regression models. In accordance with our main analysis, it suggests that the democracy quality dimensions do not matter for pollution.

Table A2. Democracy quality dimensions and commitment to climate cooperation (OLS regression analysis).

\begin{tabular}{|c|c|c|c|c|}
\hline & (1) & $(2)$ & (3) & (4) \\
\hline Population density (In) & $\begin{array}{c}.000 \\
(.010)\end{array}$ & $\begin{array}{c}.001 \\
(.010)\end{array}$ & $\begin{array}{c}.007 \\
(.009)\end{array}$ & $\begin{array}{c}.004 \\
(.010)\end{array}$ \\
\hline GDP per capita (In) & $\begin{array}{c}.003 \\
(.016)\end{array}$ & $\begin{array}{c}.007 \\
(.015)\end{array}$ & $\begin{array}{c}.004 \\
(.014)\end{array}$ & $\begin{array}{c}-.001 \\
(.015)\end{array}$ \\
\hline GDP growth & $\begin{array}{c}.003 \\
(.008)\end{array}$ & $\begin{array}{c}.005 \\
(.008)\end{array}$ & $\begin{array}{c}.006 \\
(.007)\end{array}$ & $\begin{array}{c}.004 \\
(.007)\end{array}$ \\
\hline Fuel exports (In) & $\begin{array}{c}-.011 \\
(.013)\end{array}$ & $\begin{array}{c}-.013 \\
(.012)\end{array}$ & $\begin{array}{c}-.010 \\
(.012)\end{array}$ & $\begin{array}{c}-.009 \\
(.012)\end{array}$ \\
\hline Trade openness (In) & $\begin{array}{l}.086^{* *} \\
(.035)\end{array}$ & $\begin{array}{l}.089 * * \\
(.036)\end{array}$ & $\begin{array}{l}.098^{* * *} \\
(.034)\end{array}$ & $\begin{array}{c}.066^{*} \\
(.034)\end{array}$ \\
\hline Memberships in IGOs & $\begin{array}{c}.000 \\
(.001)\end{array}$ & $\begin{array}{c}.000 \\
(.001)\end{array}$ & $\begin{array}{c}.000 \\
(.001)\end{array}$ & $\begin{array}{l}.000 \\
(.001)\end{array}$ \\
\hline ENGO strength (In) & $\begin{array}{c}.028 \\
(.022)\end{array}$ & $\begin{array}{c}.038^{*} \\
(.021)\end{array}$ & $\begin{array}{c}.035^{*} \\
(.020)\end{array}$ & $\begin{array}{c}.037^{*} \\
(.021)\end{array}$ \\
\hline Climate change vulnerability & $\begin{array}{c}.097 \\
(.101)\end{array}$ & $\begin{array}{c}-.055 \\
(.103)\end{array}$ & $\begin{array}{c}-.046 \\
(.096)\end{array}$ & $\begin{array}{c}-.037 \\
(.100)\end{array}$ \\
\hline Electoral accountability & $\begin{array}{l}.134 * * * \\
(.046)\end{array}$ & & & \\
\hline Horizontal accountability & & $\begin{array}{l}.076^{* * *} \\
(.025)\end{array}$ & & \\
\hline Political rights & & & $\begin{array}{l}.139 * * * \\
(.030)\end{array}$ & \\
\hline Civil rights & & & & $\begin{array}{l}.411^{* * *} \\
(.107)\end{array}$ \\
\hline Countries & 99 & 99 & 99 & 99 \\
\hline $\mathrm{R}^{2}$ & .374 & .378 & .445 & .411 \\
\hline
\end{tabular}

Notes: Unstandardized regression coefficients and standard errors in parentheses. ${ }^{* *} p<.01,{ }^{* *} p<.05,{ }^{*} p<.10$. The units of analysis are country averages from 1990-2005. 
Table A3. Democracy quality dimensions and $\mathrm{CO}_{2}$ emissions per capita, In (OLS regression analysis).

\begin{tabular}{|c|c|c|c|c|}
\hline & (1) & (2) & (3) & (4) \\
\hline Population density (In) & $\begin{array}{l}.095^{* *} \\
(.038)\end{array}$ & $\begin{array}{l}.091^{* *} \\
(.038)\end{array}$ & $\begin{array}{l}.088^{* *} \\
(.039)\end{array}$ & $\begin{array}{l}.095^{* *} \\
(.039)\end{array}$ \\
\hline GDP per capita (In) & $\begin{array}{l}.867^{* * *} \\
(.066)\end{array}$ & $\begin{array}{l}.907^{* * *} \\
(.060)\end{array}$ & $\begin{array}{l}.914^{* * *} \\
(.056)\end{array}$ & $\begin{array}{l}.890 * * * \\
(.062)\end{array}$ \\
\hline GDP per capita (In) squared & $\begin{array}{l}-.131 * * * \\
(.026)\end{array}$ & $\begin{array}{l}-.135^{* * *} \\
(.026)\end{array}$ & $\begin{array}{l}-.136 * * * \\
(.026)\end{array}$ & $\begin{array}{c}-.136 * * * \\
(.026)\end{array}$ \\
\hline GDP growth & $\begin{array}{c}-.085^{* *} \\
(.034)\end{array}$ & $\begin{array}{l}-.080^{* *} \\
(.034)\end{array}$ & $\begin{array}{l}-.080^{* *} \\
(.034)\end{array}$ & $\begin{array}{l}-.081^{* *} \\
(.034)\end{array}$ \\
\hline Fuel exports (In) & $\begin{array}{l}.247^{* * *} \\
(.051)\end{array}$ & $\begin{array}{l}.231^{* * *} \\
(.050)\end{array}$ & $\begin{array}{l}.228 * * * \\
(.049)\end{array}$ & $\begin{array}{l}.237^{* * *} \\
(.050)\end{array}$ \\
\hline Trade openness (In) & $\begin{array}{c}.130 \\
(.038)\end{array}$ & $\begin{array}{l}.097 \\
(.149)\end{array}$ & $\begin{array}{l}.084 \\
(.152)\end{array}$ & $\begin{array}{l}.098 \\
(.146)\end{array}$ \\
\hline Memberships in IGOs & $\begin{array}{l}-.014^{* * *} \\
(.004)\end{array}$ & $\begin{array}{l}-.014 * * * \\
(.004)\end{array}$ & $\begin{array}{l}-.013^{* * *} \\
(.004)\end{array}$ & $\begin{array}{l}-.014^{* * *} \\
(.004)\end{array}$ \\
\hline ENGO strength (In) & $\begin{array}{c}.152^{*} \\
(.085)\end{array}$ & $\begin{array}{c}.154^{*} \\
(.085)\end{array}$ & $\begin{array}{c}.152^{*} \\
(.085)\end{array}$ & $\begin{array}{c}.156^{*} \\
(.085)\end{array}$ \\
\hline Climate change vulnerability & $\begin{array}{c}-1.184^{* * *} \\
(.412)\end{array}$ & $\begin{array}{c}-1.229 * * * \\
(.417)\end{array}$ & $\begin{array}{c}-1.247^{* * *} \\
(.416)\end{array}$ & $\begin{array}{c}-1.199 * * * \\
(.416)\end{array}$ \\
\hline Commitment to climate cooperation & $\begin{array}{c}.396 \\
(.411)\end{array}$ & $\begin{array}{c}.525 \\
(.412)\end{array}$ & $\begin{array}{c}.583 \\
(.434)\end{array}$ & $\begin{array}{c}.444 \\
(.422)\end{array}$ \\
\hline Electoral accountability & $\begin{array}{c}.189 \\
(.195)\end{array}$ & & & \\
\hline Horizontal accountability & & $\begin{array}{l}.001 \\
(.106)\end{array}$ & & \\
\hline Political rights & & & $\begin{array}{l}-.045 \\
(.016)\end{array}$ & \\
\hline Civil rights & & & & $\begin{array}{c}.238 \\
(.479)\end{array}$ \\
\hline Countries & 99 & 99 & 99 & 99 \\
\hline $\mathrm{R}^{2}$ & .916 & .915 & .915 & .915 \\
\hline
\end{tabular}

Notes: Unstandardized regression coefficients and standard errors in parentheses. ${ }^{* * *} p<.01,{ }^{* *} p<.05,{ }^{*} p<.10$. The units of analysis are country averages of from 1990-2010. IGO membership, ENGO strength and commitment refer to country averages from 1990-2005. 


\section{Main Models without Influential Cases}

Table A4 and A5 present our main regression models without influential cases. First, countries with standardized residuals of at least $+/-2$ were successively excluded. Second, outliers were identified using Cook's $D(>4 / n)$, Leverage $(>3 * k / n)$ and DfBetas $(>+/-1)$. The results of our commitment models stay stable (see Table A4).

With regard to $\mathrm{CO}_{2}$ emissions per capita, the positive effect of political rights on $\mathrm{CO}_{2}$ emissions per capita becomes significant (see Table A5). However, this effect turns insignificant again if we estimate further robustness analyses with and without influential cases.

Table A4. Democracy quality dimensions and climate cooperation commitment without influential cases (OLS regression analysis).

\begin{tabular}{|c|c|c|c|c|}
\hline & (1) & $(2)$ & (3) & (4) \\
\hline Population density (In) & $\begin{array}{c}.013^{*} \\
(.007)\end{array}$ & $\begin{array}{c}.003 \\
(.006)\end{array}$ & $\begin{array}{c}.002 \\
(.007)\end{array}$ & $\begin{array}{c}.002 \\
(.007)\end{array}$ \\
\hline GDP per capita (In) & $\begin{array}{l}.008 \\
(.011)\end{array}$ & $\begin{array}{l}.014 \\
(.010)\end{array}$ & $\begin{array}{l}.008 \\
(.012)\end{array}$ & $\begin{array}{c}.021 \\
(.011)\end{array}$ \\
\hline GDP growth & $\begin{array}{l}.002 \\
(.005)\end{array}$ & $\begin{array}{l}.000 \\
(.005)\end{array}$ & $\begin{array}{c}-.003 \\
(.006)\end{array}$ & $\begin{array}{c}-.005 \\
(.006)\end{array}$ \\
\hline Fuel exports (In) & $\begin{array}{l}.003 \\
(.008)\end{array}$ & $\begin{array}{c}.014^{*} \\
(.008)\end{array}$ & $\begin{array}{c}.013 \\
(.009)\end{array}$ & $\begin{array}{c}.003 \\
(.009)\end{array}$ \\
\hline Trade openness (In) & $\begin{array}{l}.129 \\
(.025)\end{array}$ & $\begin{array}{l}.088^{* * *} \\
(.023)\end{array}$ & $\begin{array}{l}.069 * * * \\
(.026)\end{array}$ & $\begin{array}{l}.108 * * * \\
(.028)\end{array}$ \\
\hline Memberships in IGOs & $\begin{array}{c}.000 \\
(.000)\end{array}$ & $\begin{array}{l}.001^{* *} \\
(.001)\end{array}$ & $\begin{array}{c}.000 \\
(.001)\end{array}$ & $\begin{array}{c}.001 \\
(.001)\end{array}$ \\
\hline ENGO strength (In) & $\begin{array}{l}.031^{* *} \\
(.015)\end{array}$ & $\begin{array}{c}.009 \\
(.013)\end{array}$ & $\begin{array}{c}.024 \\
(.015)\end{array}$ & $\begin{array}{c}.006 \\
(.017)\end{array}$ \\
\hline Climate change vulnerability & $\begin{array}{c}.026 \\
(.065)\end{array}$ & $\begin{array}{c}-.086 \\
(.063)\end{array}$ & $\begin{array}{c}-.095 \\
(.069)\end{array}$ & $\begin{array}{c}-.137 \\
(.072)\end{array}$ \\
\hline Electoral accountability & $\begin{array}{c}-.067 \\
(.046)\end{array}$ & & & \\
\hline Horizontal accountability & $\begin{array}{c}.014 \\
(.022)\end{array}$ & & & \\
\hline Political rights & $\begin{array}{l}.169 * * * \\
(.040)\end{array}$ & & & \\
\hline Civil rights & $\begin{array}{c}.024 \\
(.119)\end{array}$ & & & \\
\hline Freedom House Political rights & & $\begin{array}{l}.039 * * * \\
(.010)\end{array}$ & & \\
\hline Freedom House Civil liberties & & & $\begin{array}{l}.065^{* * *} \\
(.014)\end{array}$ & \\
\hline Polity2 & & & & $\begin{array}{l}.009 * * \\
(.004)\end{array}$ \\
\hline Countries & 78 & 76 & 82 & 84 \\
\hline $\mathrm{R}^{2}$ & .725 & .724 & .678 & .569 \\
\hline
\end{tabular}

Notes: Unstandardized regression coefficients and standard errors in parentheses. ${ }^{* * *} p<.01,{ }^{* *} p<.05,{ }^{*} p<.10$. The units of analysis are country averages from 1990-2005. 
Table A5. Democracy quality dimensions and $\mathrm{CO}_{2}$ emissions per capita, In without influential cases (OLS regression analysis).

\begin{tabular}{|c|c|c|c|c|}
\hline & (1) & $(2)$ & (3) & (4) \\
\hline \multirow[t]{2}{*}{ Population density (In) } & .042 & .048 & .040 & $.053 *$ \\
\hline & $(.034)$ & $(.035)$ & $(.036)$ & $(.034)$ \\
\hline \multirow[t]{2}{*}{ GDP per capita (In) } & $.832 * * *$ & $.896 * * *$ & $.896 * * *$ & $.893 * * *$ \\
\hline & $(.055)$ & $(.057)$ & $(.060)$ & $(.054)$ \\
\hline \multirow[t]{2}{*}{ GDP per capita (In) squared } & $-.135 * * *$ & $-.145 * * *$ & $-.140 * * *$ & $-.143^{* * *}$ \\
\hline & $(.023)$ & $(.022)$ & $(.023)$ & $(.022)$ \\
\hline \multirow[t]{2}{*}{ GDP growth } & $-.127 * * *$ & $-.101^{* * *}$ & $-.087^{* * *}$ & $.092 * * *$ \\
\hline & $(.027)$ & $(.031)$ & $(.031)$ & $(.030)$ \\
\hline \multirow[t]{2}{*}{ Fuel exports (In) } & $.193^{* * *}$ & $.171^{* * *}$ & $.176^{* * *}$ & $.208 * * *$ \\
\hline & $(.044)$ & $(.045)$ & $(.044)$ & $(.042)$ \\
\hline \multirow[t]{2}{*}{ Trade openness (In) } & $.337^{* * *}$ & $.316 * * *$ & $.316^{* * *}$ & $.278^{* *}$ \\
\hline & $(.121)$ & $(.127)$ & $(.127)$ & $(.129)$ \\
\hline \multirow[t]{2}{*}{ Memberships in IGOs } & $-.007^{*}$ & $-.009 * *$ & $-.008 * *$ & $-.007 * *$ \\
\hline & $(.003)$ & $(.003)$ & $(.004)$ & $(.003)$ \\
\hline \multirow[t]{2}{*}{ ENGO strength (In) } & $.161^{* *}$ & $.227 * * *$ & $.222 * * *$ & .165 \\
\hline & $(.067)$ & $(.070)$ & $(.069)$ & $(.072)$ \\
\hline \multirow[t]{2}{*}{ Climate change vulnerability } & $-1.805^{* * *}$ & $-1.562 * * *$ & $-1.562 * * *$ & $-1.220 * * *$ \\
\hline & $(.357)$ & $(.374)$ & $(.380)$ & $(.369)$ \\
\hline \multirow[t]{2}{*}{ Commitment to climate cooperation } & .275 & .183 & .278 & -.222 \\
\hline & $(.342)$ & $(.366)$ & $(.388)$ & $(.369)$ \\
\hline \multirow[t]{2}{*}{ Electoral accountability } & $.355^{*}$ & & & \\
\hline & $(.207)$ & & & \\
\hline \multirow[t]{2}{*}{ Horizontal accountability } & -.054 & & & \\
\hline & $(.104)$ & & & \\
\hline \multirow[t]{2}{*}{ Political rights } & $-.413^{* *}$ & & & \\
\hline & $(.181)$ & & & \\
\hline \multirow[t]{2}{*}{ Civil rights } & .225 & & & \\
\hline & $(.538)$ & & & \\
\hline \multirow[t]{2}{*}{ Freedom House Political rights } & & -.062 & & \\
\hline & & $(.058)$ & & \\
\hline \multirow[t]{2}{*}{ Freedom House Civil liberties } & & & -.079 & \\
\hline & & & $(.072)$ & \\
\hline \multirow[t]{2}{*}{ Polity2 } & & & & -.016 \\
\hline & & & & $(.017)$ \\
\hline Countries & 86 & 88 & 90 & 86 \\
\hline $\mathrm{R}^{2}$ & .958 & .950 & .9476 .952 & \\
\hline
\end{tabular}

Notes: Unstandardized regression coefficients and standard errors in parentheses. ${ }^{* *} p<.01,{ }^{* *} p<.05,{ }^{*} p<.10$. The units of analysis are country averages of from 1990-2010. IGO membership, ENGO strength and commitment refer to country averages from 1990-2005. 


\section{Jackknife Analysis}

Using jackknife analysis, we tested whether our results depend on certain country groups. Table A6 tests the effect of our main models without developed countries. We identified developed countries by OECD-membership. The effect of political rights on commitment becomes insignificant if we exclude developed countries. However, it becomes significant if we exclude outliers. The following countries are identified as outliers in model 1 in Table A6: Central African Republic, Republic Congo, Costa Rica, Dominican Republic, Gabon, Gambia, Kuwait, New Zealand, Singapore, Ukraine, and Zambia. The results of $\mathrm{CO}_{2}$ emissions per capita model remain stable.

Table A6. Democracy quality dimensions, commitment to climate cooperation and $\mathrm{CO}_{2}$ emissions per capita, In in nondeveloped countries (OLS regression analysis).

\begin{tabular}{|c|c|c|c|c|}
\hline & $\begin{array}{l}\text { (1) Commitment } \\
\text { to climate } \\
\text { cooperation }\end{array}$ & $\begin{array}{c}\text { (2) Commitment to } \\
\text { climate cooperation } \\
\text { without influential } \\
\text { cases }\end{array}$ & $\begin{array}{l}\text { (3) } \mathrm{CO}_{2} \text { emissions } \\
\text { per capita, In }\end{array}$ & $\begin{array}{c}\text { (4) } \mathrm{CO}_{2} \text { emissions } \\
\text { per capita, } \\
\text { In without } \\
\text { influential cases }\end{array}$ \\
\hline \multirow[t]{2}{*}{ Population density (In) } & .006 & .002 & $.107^{*}$ & .016 \\
\hline & $(.011)$ & $(.009)$ & $(.053)$ & $(.042)$ \\
\hline \multirow[t]{2}{*}{ GDP per capita (In) } & .005 & .024 & $.798 * * *$ & $.723 * * *$ \\
\hline & $(.045)$ & $(.017)$ & $(.108)$ & $(.076)$ \\
\hline \multirow[t]{2}{*}{ GDP per capita (In) squared } & & & $-.121 * *$ & $-.128 * * *$ \\
\hline & & & $(.057)$ & $(.041)$ \\
\hline \multirow[t]{2}{*}{ GDP growth } & .009 & .010 & $-.122 * *$ & $-.190 * * *$ \\
\hline & $(.009)$ & $(.007)$ & $(.049)$ & $(.030)$ \\
\hline \multirow[t]{2}{*}{ Fuel exports (In) } & -.013 & $.000 * * *$ & $.290 * * *$ & $.189 * * *$ \\
\hline & $(.015)$ & $(.011)$ & $(.071)$ & $(.047)$ \\
\hline \multirow[t]{2}{*}{ Trade openness (In) } & .039 & $.066^{*}$ & .203 & $.679 * * *$ \\
\hline & $(.039)$ & $(.034)$ & $(.258)$ & $(.165)$ \\
\hline \multirow[t]{2}{*}{ Memberships in IGOs } & -.001 & -.001 & -.012 & .004 \\
\hline & $(.002)$ & $(.001)$ & $(.008)$ & $(.005)$ \\
\hline \multirow[t]{2}{*}{ ENGO strength (In) } & .012 & $.012 *$ & .165 & $.287^{* * *}$ \\
\hline & $(.026)$ & $(.020)$ & $(.125)$ & $(.079)$ \\
\hline \multirow[t]{2}{*}{ Climate change vulnerability } & .034 & .088 & $-1.157^{* *}$ & $-2.061 * * *$ \\
\hline & $(.111)$ & $(.080)$ & $(.523)$ & $(.370)$ \\
\hline \multirow[t]{2}{*}{ Commitment to climate cooperation } & & & 1.148 & $1.000 * *$ \\
\hline & & & $(.652)$ & $(.437)$ \\
\hline \multirow[t]{2}{*}{ Electoral accountability } & .056 & -.042 & .199 & -.021 \\
\hline & $(.071)$ & $(.053)$ & $(.353)$ & $(.222)$ \\
\hline \multirow[t]{2}{*}{ Horizontal accountability } & -.002 & -.002 & -.033 & -.034 \\
\hline & $(.035)$ & $(.027)$ & $(.171)$ & $(.108)$ \\
\hline \multirow[t]{2}{*}{ Political rights } & .065 & $.084^{*}$ & -.201 & .217 \\
\hline & $(.056)$ & $(.048)$ & $(.307)$ & $(.200)$ \\
\hline \multirow[t]{2}{*}{ Civil rights } & .084 & .144 & .357 & -.122 \\
\hline & $(.173)$ & $(.139)$ & $(.918)$ & $(.589)$ \\
\hline Countries & 68 & 57 & 68 & 56 \\
\hline $\mathrm{R}^{2}$ & .321 & .488 & .891 & .962 \\
\hline
\end{tabular}

Notes: Unstandardized regression coefficients and standard errors in parentheses. ${ }^{* * *} p<.01, * * p<.05, * p<.10$. The units of analysis are country averages of from 1990-2005 (Model 1-2) and from 1990-2010 (Model 2-4). IGO membership, ENGO strength and commitment refer to country averages from 1990-2005.

The results of our analysis of commitment to climate cooperation also remain stable if we exclude countries from particular regions. Tables A7, A8 and A9 summarize the results of our jackknife-analysis. We applied the World Bank country classification by region (https://datahelpdesk.worldbank.org/knowledgebase/articles/906519-world-bank-country-and-lendinggroups). The positive effect of political rights on commitment to climate cooperation remains significant in nearly all regression models (see Table A6). It becomes marginally insignificant if countries from East European or from Southeastern European countries are removed from the analysis. However, if we estimate the models without influential cases the effect of political rights becomes significant again (see Table A7). If we exclude countries from Sub-Sahara Africa, we find a significant negative effect of electoral accountability on commitment. In addition, several models without outliers exhibit 
a significant negative effect of electoral accountability and a significant positive effect of civil rights on commitment. However, these effects are not as robust as the effect of political rights. In our analysis without countries from the Middle East and North Africa, electoral accountability is significantly associated with $\mathrm{CO}_{2}$ emissions per capita (see Table A9). Model 2 and 4 in table A14 show that the significant positive effect of electoral accountability, in the analysis of our sample without countries from the Middle East and Northern Africa, is only stable for the period from 1990-1999. Political rights are negatively associated with $\mathrm{CO}_{2}$ emissions per capita if we exclude countries from Central Asia or Latin America (see Model 1 and 4 in Table A9). However, this effect becomes insignificant if we estimate further robustness analyses.

Table A7. Jackknife analysis: Democracy quality dimensions and commitment to climate cooperation (OLS regression analysis).

\begin{tabular}{|c|c|c|c|c|c|c|c|c|c|c|}
\hline & $\begin{array}{c}(1) \\
\text { Central } \\
\text { Asia }\end{array}$ & $\begin{array}{c}\text { (2) } \\
\text { East } \\
\text { Asia and } \\
\text { Pacific }\end{array}$ & $\begin{array}{c}\text { (3) } \\
\text { East } \\
\text { Europe }\end{array}$ & $\begin{array}{c}(4) \\
\text { Latin } \\
\text { American }\end{array}$ & $\begin{array}{c}(5) \\
\text { Middle } \\
\text { East and } \\
\text { North } \\
\text { Africa }\end{array}$ & $\begin{array}{c}(6) \\
\text { North } \\
\text { America }\end{array}$ & $\begin{array}{c}\text { (7) } \\
\text { South } \\
\text { Asia }\end{array}$ & $\begin{array}{c}(8) \\
\text { South } \\
\text { East } \\
\text { Europe }\end{array}$ & $\begin{array}{c}\text { (9) } \\
\text { Sub- } \\
\text { Saharan } \\
\text { Africa }\end{array}$ & $\begin{array}{c}(10) \\
\text { Western } \\
\text { European }\end{array}$ \\
\hline $\begin{array}{l}\text { Population } \\
\text { density (In) }\end{array}$ & $\begin{array}{l}.008 \\
(.068)\end{array}$ & $\begin{array}{l}.016 \\
(.011)\end{array}$ & $\begin{array}{l}.008 \\
(.010)\end{array}$ & $\begin{array}{c}.005 \\
(.012)\end{array}$ & & $\begin{array}{l}.009 \\
(.010)\end{array}$ & $\begin{array}{l}.012 \\
(.010)\end{array}$ & $\begin{array}{c}.006 \\
(.010)\end{array}$ & & \\
\hline $\begin{array}{l}\text { GDP per capita } \\
\text { (In) }\end{array}$ & $\begin{array}{l}-.002 \\
(-.015)\end{array}$ & $\begin{array}{l}-.005 \\
(.018)\end{array}$ & & & & & & & & $\begin{array}{l}-.004 \\
(0.18)\end{array}$ \\
\hline GDP growth & $\begin{array}{l}.007 \\
(.008)\end{array}$ & $\begin{array}{l}.004 \\
(.008)\end{array}$ & $\begin{array}{l}-.001 \\
(.009)\end{array}$ & & & & $\begin{array}{l}.008 \\
(.008)\end{array}$ & $\begin{array}{l}.006 \\
(.008)\end{array}$ & & $\begin{array}{l}.008 \\
(.008)\end{array}$ \\
\hline Fuel exports (In) & $\begin{array}{l}-.008 \\
(.012)\end{array}$ & $\begin{array}{l}-.006 \\
(.013)\end{array}$ & $\begin{array}{l}-.009 \\
(.013)\end{array}$ & $\begin{array}{l}-.011 \\
(.015)\end{array}$ & $\begin{array}{l}.000 \\
(.012)\end{array}$ & $\begin{array}{l}-.009 \\
(.012)\end{array}$ & $\begin{array}{l}-.007 \\
(.013)\end{array}$ & $\begin{array}{l}-.012 \\
(.012)\end{array}$ & & $\begin{array}{l}-.003 \\
(.014)\end{array}$ \\
\hline $\begin{array}{l}\text { Trade openness } \\
\text { (In) }\end{array}$ & $\begin{array}{l}.091^{* *} \\
(.035)\end{array}$ & $\begin{array}{l}.085^{* *} \\
(.018)\end{array}$ & $\begin{array}{l}.097^{* * *} \\
(.036)\end{array}$ & $\begin{array}{l}.115^{* * *} \\
(.041)\end{array}$ & $\begin{array}{l}.073^{* *} \\
(.036)\end{array}$ & $\begin{array}{l}.079 * * \\
(.036)\end{array}$ & $\begin{array}{l}.089 * * \\
(.037)\end{array}$ & $\begin{array}{l}.082^{* *} \\
(.035)\end{array}$ & $\begin{array}{l}.094^{* *} \\
(.038)\end{array}$ & $\begin{array}{l}.073^{*} \\
(.042)\end{array}$ \\
\hline $\begin{array}{l}\text { Memberships } \\
\text { in IGOs }\end{array}$ & $\begin{array}{l}.000 \\
(.001)\end{array}$ & $\begin{array}{l}.000 \\
(.001)\end{array}$ & & $\begin{array}{l}.000 \\
(.001)\end{array}$ & $\begin{array}{l}-.001 \\
(.001)\end{array}$ & & $\begin{array}{l}.000 \\
(.001)\end{array}$ & $\begin{array}{l}.000 \\
(.001)\end{array}$ & & $\begin{array}{l}-.001 \\
(.001)\end{array}$ \\
\hline $\begin{array}{l}\text { ENGO strength } \\
\text { (In) }\end{array}$ & $\begin{array}{l}.035^{*} \\
(.021)\end{array}$ & $\begin{array}{l}.047^{* *} \\
(.022)\end{array}$ & $\begin{array}{l}.042^{* *} \\
(.021)\end{array}$ & $\begin{array}{l}.037 \\
(.024)\end{array}$ & $\begin{array}{l}.024 \\
(.021)\end{array}$ & $\begin{array}{l}.038^{*} \\
(.021)\end{array}$ & $\begin{array}{l}.050 * * \\
(.023)\end{array}$ & $\begin{array}{c}.023 \\
(.021)\end{array}$ & $\begin{array}{l}.031 \\
(.168)\end{array}$ & $\begin{array}{l}.030 \\
(.024)\end{array}$ \\
\hline $\begin{array}{l}\text { Climate change } \\
\text { vulnerability }\end{array}$ & $\begin{array}{l}-.024 \\
(.100) \\
\end{array}$ & $\begin{array}{l}-.005 \\
(.102) \\
\end{array}$ & $\begin{array}{l}-.018 \\
(.106) \\
\end{array}$ & $\begin{array}{c}.032 \\
(.188) \\
\end{array}$ & $\begin{array}{l}-.040 \\
(.099) \\
\end{array}$ & $\begin{array}{l}-.039 \\
(.099)\end{array}$ & $\begin{array}{l}-.081 \\
(.109) \\
\end{array}$ & $\begin{array}{l}-.058 \\
(.100)\end{array}$ & $\begin{array}{c}.011 \\
(.100) \\
\end{array}$ & $\begin{array}{c}.003 \\
(.066) \\
\end{array}$ \\
\hline $\begin{array}{l}\text { Electoral } \\
\text { accountability }\end{array}$ & $\begin{array}{c}-.006 \\
(.061)\end{array}$ & $\begin{array}{c}-.028 \\
(.062)\end{array}$ & $\begin{array}{c}-.015 \\
(.062)\end{array}$ & $\begin{array}{l}.018 \\
(.074)\end{array}$ & $\begin{array}{l}.021 \\
(.062)\end{array}$ & $\begin{array}{c}-.024 \\
(.061)\end{array}$ & $\begin{array}{l}-.021 \\
(.065)\end{array}$ & $\begin{array}{l}.058 \\
(.062)\end{array}$ & & \\
\hline $\begin{array}{l}\text { Horizontal } \\
\text { accountability }\end{array}$ & $\begin{array}{l}.011 \\
(.032)\end{array}$ & $\begin{array}{l}.016 \\
(.032)\end{array}$ & $\begin{array}{l}.014 \\
(.032)\end{array}$ & $\begin{array}{l}-.007 \\
(.039)\end{array}$ & $\begin{array}{l}.015 \\
(.073)\end{array}$ & & $\begin{array}{c}.016 \\
(.034)\end{array}$ & $\begin{array}{c}.014 \\
(.032)\end{array}$ & $\begin{array}{l}.005 \\
(.035)\end{array}$ & \\
\hline Political rights & $\begin{array}{l}.107^{* *} \\
(.049)\end{array}$ & $\begin{array}{l}.099^{*} \\
(.058)\end{array}$ & $\begin{array}{l}.083 \\
(.108) \\
.051)\end{array}$ & $\begin{array}{l}.131^{* *} \\
(.060)\end{array}$ & $\begin{array}{l}.095^{*} \\
(.052)\end{array}$ & $\begin{array}{l}.112^{* *} \\
(.049)\end{array}$ & $\begin{array}{l}.124^{* *} \\
(.052)\end{array}$ & $\begin{array}{c}.071 \\
(.157) \\
.050)\end{array}$ & $\begin{array}{l}.136^{* *} \\
(.055)\end{array}$ & $\begin{array}{l}.102^{*} \\
(.054)\end{array}$ \\
\hline Civil rights & $\begin{array}{l}.126 \\
(.161)\end{array}$ & $\begin{array}{l}.206 \\
(.187)\end{array}$ & $\begin{array}{l}.162 \\
(.160)\end{array}$ & $\begin{array}{l}.205 \\
(.183)\end{array}$ & $\begin{array}{l}.100 \\
(.158)\end{array}$ & $\begin{array}{c}.142 \\
(.158)\end{array}$ & $\begin{array}{c}.071 \\
(.171)\end{array}$ & $\begin{array}{c}.042 \\
(.158)\end{array}$ & $\begin{array}{c}.267 \\
(.199)\end{array}$ & $\begin{array}{c}.167 \\
(.169)\end{array}$ \\
\hline & & & & & & & & & & \\
\hline
\end{tabular}

Notes: Unstandardized regression coefficients and standard errors in parentheses. ${ }^{* * *} p<.01,{ }^{* *} p<.05,{ }^{*} p<.10$. The units of analysis are country averages from 1990-2005. 
Table A8. Jackknife analysis: Democracy quality dimensions and commitment to climate cooperation without outliers (OLS regression analysis).

\begin{tabular}{|c|c|c|c|c|c|c|c|c|c|c|}
\hline & $\begin{array}{c}(1) \\
\text { Central } \\
\text { Asia }\end{array}$ & $\begin{array}{c}\text { (2) } \\
\text { East } \\
\text { Asia and } \\
\text { Pacific }\end{array}$ & $\begin{array}{c}\text { (3) } \\
\text { East } \\
\text { Europe }\end{array}$ & $\begin{array}{c}(4) \\
\text { Latin } \\
\text { American }\end{array}$ & $\begin{array}{c}(5) \\
\text { Middle } \\
\text { East and } \\
\text { North } \\
\text { Africa }\end{array}$ & $\begin{array}{c}(6) \\
\text { North } \\
\text { America }\end{array}$ & $\begin{array}{c}(7) \\
\text { South } \\
\text { Asia }\end{array}$ & $\begin{array}{c}\text { (8) } \\
\text { South } \\
\text { East } \\
\text { Europe }\end{array}$ & $\begin{array}{c}\text { (9) } \\
\text { Sub- } \\
\text { Saharan } \\
\text { Africa }\end{array}$ & $\begin{array}{c}\text { (10) } \\
\text { Western } \\
\text { European }\end{array}$ \\
\hline $\begin{array}{l}\text { Population } \\
\text { density (In) }\end{array}$ & $\begin{array}{c}.008 \\
(.007)\end{array}$ & $\begin{array}{l}.013^{*} \\
(.008)\end{array}$ & $\begin{array}{l}.015^{* *} \\
(.006)\end{array}$ & $\begin{array}{l}.019 * * * \\
(.007)\end{array}$ & $\begin{array}{l}.015 * * \\
(.007)\end{array}$ & $\begin{array}{l}.020 * * * \\
(.006)\end{array}$ & $\begin{array}{l}.019 * * * \\
(.007)\end{array}$ & $\begin{array}{c}* 006 \\
(.007)\end{array}$ & $\begin{array}{c}.005 \\
(.008)\end{array}$ & $\begin{array}{l}.007 \\
(.010)\end{array}$ \\
\hline $\begin{array}{l}\text { GDP per capita } \\
\text { (In) }\end{array}$ & $\begin{array}{l}.017 \\
(.012)\end{array}$ & $\begin{array}{l}.010 \\
(.013)\end{array}$ & $\begin{array}{l}.007 \\
(.010)\end{array}$ & $\begin{array}{l}.000 \\
(.010)\end{array}$ & $\begin{array}{l}.008 \\
(.012)\end{array}$ & $\begin{array}{l}.008 \\
(.010)\end{array}$ & $\begin{array}{c}.004 \\
(.005)\end{array}$ & $\begin{array}{c}.003 \\
(.011)\end{array}$ & $\begin{array}{l}.015 \\
(.013)\end{array}$ & $\begin{array}{l}.015 \\
(.013)\end{array}$ \\
\hline GDP growth & $\begin{array}{l}.003 \\
(.006)\end{array}$ & $\begin{array}{l}.001 \\
(.006)\end{array}$ & $\begin{array}{l}.005 \\
.005)\end{array}$ & $\begin{array}{l}.010 \\
(.005)\end{array}$ & $\begin{array}{l}.000 \\
(.006)\end{array}$ & $\begin{array}{l}.012 * * * \\
(.004)\end{array}$ & $\begin{array}{l}.019 * * * \\
(.007)\end{array}$ & $\begin{array}{l}{ }^{*}-.001 \\
(.005)\end{array}$ & $\begin{array}{l}.012^{* *} \\
(.006)\end{array}$ & $\begin{array}{l}.012^{*} \\
(.006)\end{array}$ \\
\hline Fuel exports (In) & $\begin{array}{l}.005 \\
(.008)\end{array}$ & $\begin{array}{l}.001 \\
(.009)\end{array}$ & $\begin{array}{l}.005 \\
(.007)\end{array}$ & $\begin{array}{l}.021^{* *} \\
(.009)\end{array}$ & $\begin{array}{l}.005 \\
(.008)\end{array}$ & $\begin{array}{l}.019 * * \\
(.007)\end{array}$ & $\begin{array}{l}.001 \\
(.008)\end{array}$ & $\begin{array}{l}.006 \\
(.007)\end{array}$ & $\begin{array}{l}.010 \\
(.008)\end{array}$ & $\begin{array}{l}.009 \\
(.010)\end{array}$ \\
\hline $\begin{array}{l}\text { Trade openness } \\
(\ln )\end{array}$ & $\begin{array}{l}.125^{* * *} \\
(.026)\end{array}$ & $\begin{array}{l}.091^{* * *} \\
(.032)\end{array}$ & $\begin{array}{l}.142^{* * *} \\
(.022)\end{array}$ & $\begin{array}{l}.146 * * * \\
(.025)\end{array}$ & $\begin{array}{l}.122^{* * *} \\
(.027)\end{array}$ & $\begin{array}{l}.124^{* * *} \\
(.021)\end{array}$ & $\begin{array}{l}.132 \\
(.013)\end{array}$ & $\begin{array}{l}.157^{* * *} \\
(.024)\end{array}$ & $\begin{array}{l}.116^{* * *} \\
(.025)\end{array}$ & $\begin{array}{l}.084 * * * \\
(.030)\end{array}$ \\
\hline $\begin{array}{l}\text { Memberships } \\
\text { in IGOs }\end{array}$ & $\begin{array}{c}.000 \\
(.001)\end{array}$ & $\begin{array}{l}-.001 \\
(.001)\end{array}$ & $\begin{array}{l}.001 \\
(.001)\end{array}$ & $\begin{array}{l}.000 \\
(.001)\end{array}$ & $\begin{array}{c}-.001 \\
(.001)\end{array}$ & $\begin{array}{l}.000 \\
(.001)\end{array}$ & $\begin{array}{c}-.001 \\
(.001)\end{array}$ & $\begin{array}{c}.000 \\
(.001)\end{array}$ & $\begin{array}{c}.001 \\
(.001)\end{array}$ & $\begin{array}{l}-.001 \\
(.001)\end{array}$ \\
\hline $\begin{array}{l}\text { ENGO strength } \\
\text { (In) }\end{array}$ & $\begin{array}{l}.039 * * \\
(.015)\end{array}$ & $\begin{array}{l}.056^{* * *} \\
(.018)\end{array}$ & $\begin{array}{l}.047^{* * *} \\
(.013)\end{array}$ & $\begin{array}{l}.047^{* * *} \\
(.013)\end{array}$ & $\begin{array}{l}.033^{* *} \\
(.016)\end{array}$ & $\begin{array}{l}.044 * * * \\
(.012)\end{array}$ & $\begin{array}{l}.058^{* * *} \\
(.016)\end{array}$ & $\begin{array}{c}.040 * * * \\
(.015)\end{array}$ & $\begin{array}{c}.044^{* *} \\
(.016)\end{array}$ & $\begin{array}{c}.021 \\
(.018)\end{array}$ \\
\hline $\begin{array}{l}\text { Climate change } \\
\text { vulnerability }\end{array}$ & $\begin{array}{c}-.003 \\
(.068)\end{array}$ & $\begin{array}{c}.012 \\
(.069)\end{array}$ & $\begin{array}{c}.104^{*} \\
(.058)\end{array}$ & $\begin{array}{l}.278^{* *} \\
(.107)\end{array}$ & $\begin{array}{l}.021 \\
(.067)\end{array}$ & $\begin{array}{l}.173^{* * *} \\
(.062)\end{array}$ & $\begin{array}{l}-.055 \\
(.073)\end{array}$ & $\begin{array}{l}-.009 \\
(.063)\end{array}$ & $\begin{array}{c}.082 \\
(.063)\end{array}$ & $\begin{array}{l}.081 \\
(.076)\end{array}$ \\
\hline $\begin{array}{l}\text { Electoral } \\
\text { accountability }\end{array}$ & $\begin{array}{l}-.058 \\
(.045)\end{array}$ & $\begin{array}{l}-.088^{*} \\
(.049)\end{array}$ & $\begin{array}{l}-.088 * * \\
(.038)\end{array}$ & $\begin{array}{l}-.028 \\
(.042)\end{array}$ & $\begin{array}{l}-.040 \\
(.049)\end{array}$ & $\begin{array}{l}-.094 * * * \\
(.034)\end{array}$ & $\begin{array}{l}-.085^{*} \\
(.046)\end{array}$ & $\begin{array}{c}-.043 \\
(.043)\end{array}$ & $\begin{array}{l}-.145^{* * *} \\
(.022)\end{array}$ & $\begin{array}{l}-.033 \\
(.049)\end{array}$ \\
\hline $\begin{array}{l}\text { Horizontal } \\
\text { accountability }\end{array}$ & $\begin{array}{l}.00 \\
(.022)\end{array}$ & $\begin{array}{c}.045^{*} \\
(.023)\end{array}$ & $\begin{array}{l}.006 \\
(.020)\end{array}$ & $\begin{array}{l}-.018 \\
(.020)\end{array}$ & $\begin{array}{c}.004 \\
(.024)\end{array}$ & $\begin{array}{c}.004 \\
(.018)\end{array}$ & $\begin{array}{c}.028 \\
(.023)\end{array}$ & $\begin{array}{c}.013 \\
(.021)\end{array}$ & $\begin{array}{c}.003 \\
(.022)\end{array}$ & $\begin{array}{l}-.016 \\
(.026)\end{array}$ \\
\hline Political rights & $\begin{array}{l}.143^{* * *} \\
(.040)\end{array}$ & $\begin{array}{l}.146^{* * *} \\
(.048)\end{array}$ & $\begin{array}{l}.126^{* * *} \\
(.034)\end{array}$ & $\begin{array}{l}.113^{* * *} \\
(.037)\end{array}$ & $\begin{array}{l}.201^{* * *} \\
(.046)\end{array}$ & $\begin{array}{l}.123^{* * *} \\
(.032)\end{array}$ & $\begin{array}{l}.211^{* * *} \\
(.039)\end{array}$ & $\begin{array}{c}.151^{* * *} \\
(.038)\end{array}$ & $\begin{array}{l}.142^{* * *} \\
(.038)\end{array}$ & $\begin{array}{l}.091^{*} \\
(.045)\end{array}$ \\
\hline Civil rights & $\begin{array}{c}.073 \\
(.122)\end{array}$ & $\begin{array}{c}.097 \\
(.135)\end{array}$ & $\begin{array}{c}.156 \\
(.099)\end{array}$ & $\begin{array}{l}.269^{* *} \\
(.113)\end{array}$ & $\begin{array}{c}-.029 \\
(.123)\end{array}$ & $\begin{array}{l}.271^{* * *} \\
(.096)\end{array}$ & $\begin{array}{l}-.089 \\
(.120)\end{array}$ & $\begin{array}{c}.051 \\
(.109)\end{array}$ & $\begin{array}{c}.239 * \\
(.122)\end{array}$ & $\begin{array}{c}.204 \\
(.131)\end{array}$ \\
\hline & 80 & 72 & 67 & 60 & 77 & 74 & 76 & 71 & 60 & 70 \\
\hline $\mathrm{R}^{2}$ & .726 & .736 & .797 & .843 & .739 & .815 & .730 & .789 & .784 & .577 \\
\hline
\end{tabular}

Notes: Unstandardized regression coefficients and standard errors in parentheses. ${ }^{* * *} p<.01,{ }^{* *} p<.05,{ }^{*} p<.10$. The units of analysis are country averages from 1990-2005. 
Table A9. Jackknife analysis: Democracy quality dimensions and $\mathrm{CO}_{2}$ emissions per capita, In (OLS regression analysis)

\begin{tabular}{|c|c|c|c|c|c|c|c|c|c|c|}
\hline & $\begin{array}{c}(1) \\
\text { Central } \\
\text { Asia }\end{array}$ & $\begin{array}{c}\text { (2) } \\
\text { East } \\
\text { Asia and } \\
\text { Pacific }\end{array}$ & $\begin{array}{c}\text { (3) } \\
\text { East } \\
\text { Europe }\end{array}$ & $\begin{array}{c}(4) \\
\text { Latin } \\
\text { American }\end{array}$ & $\begin{array}{c}(5) \\
\text { Middle } \\
\text { East and } \\
\text { North } \\
\text { Africa }\end{array}$ & $\begin{array}{c}(6) \\
\text { North } \\
\text { America }\end{array}$ & $\begin{array}{c}\text { (7) } \\
\text { South } \\
\text { Asia }\end{array}$ & $\begin{array}{l}\text { (8) } \\
\text { South } \\
\text { East } \\
\text { Europe }\end{array}$ & $\begin{array}{c}\text { (9) } \\
\text { Sub- } \\
\text { Saharan } \\
\text { Africa }\end{array}$ & $\begin{array}{c}(10) \\
\text { Western } \\
\text { European }\end{array}$ \\
\hline $\begin{array}{l}\text { Population } \\
\text { density (In) }\end{array}$ & $\begin{array}{l}.086 * * \\
(.039)\end{array}$ & $\begin{array}{l}.142 * * * \\
(.045)\end{array}$ & $\begin{array}{l}.086 * * \\
(.040)\end{array}$ & $\begin{array}{c}.011 \\
(.043)\end{array}$ & $\begin{array}{l}.098^{* *} \\
(.039)\end{array}$ & $\begin{array}{l}.098^{* *} \\
(.040)\end{array}$ & $\begin{array}{c}.069 \\
(.042)\end{array}$ & $\begin{array}{l}.086 * * \\
(.040)\end{array}$ & $\begin{array}{c}.036 \\
(.042)\end{array}$ & $\begin{array}{l}.098 * * \\
(.045)\end{array}$ \\
\hline $\begin{array}{l}\text { GDP per capita } \\
\text { (In) }\end{array}$ & $\begin{array}{l}.865^{* * *} \\
(.070)\end{array}$ & $\begin{array}{l}.866^{* * *} \\
(.072)\end{array}$ & $\begin{array}{l}.877^{* * * *} \\
(.072)\end{array}$ & $\begin{array}{l}* 846^{* * *} \\
(.070)\end{array}$ & $\begin{array}{l}.810 * * * \\
(.071)\end{array}$ & $\begin{array}{l}.832^{* * *} \\
(.070)\end{array}$ & $\begin{array}{l}.891^{* * *} \\
(.071)\end{array}$ & $\begin{array}{c}.887 * * * \\
(.072)\end{array}$ & $\begin{array}{l}.771^{* * * *} \\
(.100)\end{array}$ & $\begin{array}{l}.863^{* * *} \\
(.080)\end{array}$ \\
\hline $\begin{array}{l}\text { GDP per capita } \\
\text { (In) squared }\end{array}$ & $\begin{array}{l}-.131^{* * *} \\
(.028)\end{array}$ & $\begin{array}{c}-.109 * * * \\
(.030)\end{array}$ & $\begin{array}{l}-.128 * * * \\
(.029)\end{array}$ & $\begin{array}{c}* .173 * * * \\
(.028)\end{array}$ & $\begin{array}{l}-.115^{* * *} \\
(.030)\end{array}$ & $\begin{array}{l}-.136 * * * \\
(.028)\end{array}$ & $\begin{array}{c}-.125^{* * *} \\
(.028)\end{array}$ & $\begin{array}{c}*-.124 * * * \\
(.029)\end{array}$ & $\begin{array}{c}* .096^{* *} \\
(.041)\end{array}$ & $\begin{array}{l}-.096 * * \\
(.037)\end{array}$ \\
\hline GDP growth & $\begin{array}{l}-.082 * * \\
(.036)\end{array}$ & $\begin{array}{l}-.109 * * * \\
(.030)\end{array}$ & $\begin{array}{l}-.055 \\
(.040)\end{array}$ & $\begin{array}{l}-.093^{* *} \\
(.036)\end{array}$ & $\begin{array}{l}-.115^{* * *} \\
(.035)\end{array}$ & $\begin{array}{l}-.096 * * * \\
(.035)\end{array}$ & $\begin{array}{c}-.105^{* * *} \\
(.035)\end{array}$ & $\begin{array}{c}*-.083 * * \\
(.036)\end{array}$ & $\begin{array}{c}-.062 \\
(.042)\end{array}$ & $\begin{array}{l}-.113^{* * * *} \\
(.040)\end{array}$ \\
\hline Fuel exports (In) & $\begin{array}{l}.240 * * * \\
(.052)\end{array}$ & $\begin{array}{l}.260^{* * *} \\
(.053)\end{array}$ & $\begin{array}{l}.241^{* * *} \\
(.054)\end{array}$ & $\begin{array}{l}.219 * * * \\
(.057)\end{array}$ & $\begin{array}{l}.274^{* * *} \\
(.054)\end{array}$ & $\begin{array}{l}.253^{* * *} \\
(.051)\end{array}$ & $\begin{array}{l}.227^{* * *} \\
(.052)\end{array}$ & $\begin{array}{l}.254^{* * *} \\
(.053)\end{array}$ & $\begin{array}{l}.258^{* * *} \\
(.060)\end{array}$ & $\begin{array}{l}.257^{* * *} \\
(.059)\end{array}$ \\
\hline $\begin{array}{l}\text { Trade openness } \\
\text { (In) }\end{array}$ & $\begin{array}{c}.067 \\
(.158)\end{array}$ & $\begin{array}{c}.050 \\
(.178)\end{array}$ & $\begin{array}{l}.032 \\
(.161)\end{array}$ & $\begin{array}{c}-.065 \\
(.171)\end{array}$ & $\begin{array}{c}.098 \\
(.156)\end{array}$ & $\begin{array}{l}.104 \\
(.158)\end{array}$ & $\begin{array}{c}.083 \\
(.156)\end{array}$ & $\begin{array}{l}.023 \\
(.162)\end{array}$ & $\begin{array}{c}.166 \\
(.180)\end{array}$ & $\begin{array}{c}.204 \\
(.205)\end{array}$ \\
\hline $\begin{array}{l}\text { Memberships } \\
\text { in IGOs }\end{array}$ & $\begin{array}{l}-.013^{* * *} \\
(.004)\end{array}$ & $\begin{array}{c}-.016^{* * *} \\
(.005)\end{array}$ & $\begin{array}{l}-.015^{* * *} \\
(.005)\end{array}$ & $\begin{array}{c}-.009 * * \\
(.004)\end{array}$ & $\begin{array}{l}-.015^{* * *} \\
(.004)\end{array}$ & $\begin{array}{l}-.013^{* * *} \\
(.004)\end{array}$ & $\begin{array}{c}-.014^{* * *} \\
(.004)\end{array}$ & $\begin{array}{c}*-.015 * * * \\
(.004)\end{array}$ & $\begin{array}{r}-.008 \\
(.005)\end{array}$ & $\begin{array}{l}-.010 \\
(.006)\end{array}$ \\
\hline $\begin{array}{l}\text { ENGO strength } \\
\text { (In) }\end{array}$ & $\begin{array}{c}.133 \\
(.086)\end{array}$ & $\begin{array}{l}.184^{* *} \\
(.091)\end{array}$ & $\begin{array}{l}.100 \\
(.088)(0\end{array}$ & $088)^{.193^{* *}}$ & $\begin{array}{c}.130 \\
(.086)\end{array}$ & $\begin{array}{c}.096 \\
(.088)\end{array}$ & $\begin{array}{c}.100 \\
(.093)\end{array}$ & $\begin{array}{c}.146 \\
(.089)\end{array}$ & $\begin{array}{c}.057 \\
(.111)\end{array}$ & $\begin{array}{c}.275^{*} \\
(.101)\end{array}$ \\
\hline $\begin{array}{l}\text { Climate change } \\
\text { vulnerability }\end{array}$ & $\begin{array}{c}-1.190 * * * \\
(.420)\end{array}$ & $\begin{array}{c}* 1.003^{* *} \\
(.424)\end{array}$ & $\begin{array}{c}-1.204^{* * *} \\
(.455)\end{array}$ & $\begin{array}{c}* 2.617^{* * *} \\
(.699)\end{array}$ & $\begin{array}{c}-1.146^{* * *} \\
(.415)\end{array}$ & $\begin{array}{c}-1.187^{* * *} \\
(.417)\end{array}$ & $\begin{array}{c}-.886^{*} \\
(.447)\end{array}$ & $\begin{array}{c}-1.152^{* *} \\
(.439)\end{array}$ & $\begin{array}{c}-1.169 * * \\
(.447)\end{array}$ & $\begin{array}{c}-1.218^{* * *} \\
(.453)\end{array}$ \\
\hline $\begin{array}{l}\text { Commitment } \\
\text { to climate } \\
\text { cooperation }\end{array}$ & $\begin{array}{l}.517 \\
(.438)\end{array}$ & $\begin{array}{l}.278 \\
(.457)\end{array}$ & $\begin{array}{l}.735 \\
(.466)\end{array}$ & $\begin{array}{l}.581 \\
(.452)\end{array}$ & $\begin{array}{l}.483 \\
(.445)\end{array}$ & $\begin{array}{l}.594 \\
(.441)\end{array}$ & $\begin{array}{l}.624 \\
(.435)\end{array}$ & $\begin{array}{l}.683 \\
(.470)\end{array}$ & $\begin{array}{l}.056 \\
(.542)\end{array}$ & $\begin{array}{l}.748 \\
(.504)\end{array}$ \\
\hline $\begin{array}{l}\text { Electoral } \\
\text { accountability }\end{array}$ & $\begin{array}{c}.360 \\
(.268)\end{array}$ & $\begin{array}{c}.364 \\
(.270)\end{array}$ & $\begin{array}{c}.337 \\
(.273)\end{array}$ & $\begin{array}{l}.450 \\
(.283)\end{array}$ & $\begin{array}{c}.514^{*} \\
(.283)\end{array}$ & $\begin{array}{c}.404 \\
(.268)\end{array}$ & $\begin{array}{c}.300 \\
(.279)\end{array}$ & $\begin{array}{c}.225 \\
(.283)\end{array}$ & $\begin{array}{c}.142 \\
(.369)\end{array}$ & $\begin{array}{l}.252 \\
(.293)\end{array}$ \\
\hline $\begin{array}{l}\text { Horizontal } \\
\text { accountability }\end{array}$ & $\begin{array}{l}-.030 \\
(.136)\end{array}$ & $\begin{array}{l}-.057 \\
(.135)\end{array}$ & $\begin{array}{l}-.017 \\
(.140)\end{array}$ & $\begin{array}{c}.097 \\
(.150)\end{array}$ & $\begin{array}{l}-.129 \\
(.138)\end{array}$ & $\begin{array}{l}-.013 \\
(.135)\end{array}$ & $\begin{array}{l}-.078 \\
(.143)\end{array}$ & $\begin{array}{c}-.079 \\
(.141)\end{array}$ & $\begin{array}{l}-.027 \\
(.161)\end{array}$ & $\begin{array}{c}.006 \\
(.154)\end{array}$ \\
\hline Political rights & $\begin{array}{l}-.233 \\
(.212)\end{array}$ & $\begin{array}{l}-.453^{*} \\
(.237)\end{array}$ & $\begin{array}{l}-.211 \\
(.218)\end{array}$ & $\begin{array}{l}-.614^{* *} \\
(.017)\end{array}$ & $\begin{array}{l}-.060 \\
(.260)\end{array}$ & $\begin{array}{l}-.289 \\
(.212)\end{array}$ & $\begin{array}{l}-.323 \\
(.220)\end{array}$ & $\begin{array}{l}-.189 \\
(.219)\end{array}$ & $\begin{array}{l}-.175 \\
(.261)\end{array}$ & $\begin{array}{l}-.065 \\
(.780)\end{array}$ \\
\hline Civil rights & $\begin{array}{l}.316 \\
(.678)\end{array}$ & $\begin{array}{l}1.168 \\
(.773)\end{array}$ & $\begin{array}{l}.355 \\
(.685)\end{array}$ & $\begin{array}{l}.265 \\
(.028)\end{array}$ & $\begin{array}{l}.260 \\
(.670)\end{array}$ & $\begin{array}{l}.373 \\
(.669)\end{array}$ & $\begin{array}{c}.843 \\
(.710)\end{array}$ & $\begin{array}{c}.469 \\
(.690)\end{array}$ & $\begin{array}{c}.672 \\
(.917)\end{array}$ & $\begin{array}{c}.065 \\
(.780)\end{array}$ \\
\hline $\begin{array}{l}\text { Countries } \\
\mathrm{R}^{2}\end{array}$ & $\begin{array}{l}98 \\
.919\end{array}$ & $\begin{array}{r}87 \\
.928\end{array}$ & $\begin{array}{l}90 \\
.920\end{array}$ & \begin{tabular}{l}
\multicolumn{1}{l}{78} \\
.944
\end{tabular} & $\begin{array}{l}95 \\
.922\end{array}$ & $\begin{array}{l}97.918 \\
.918\end{array}$ & $\begin{array}{l}94 \\
.920\end{array}$ & $\begin{array}{l}93 \\
.922\end{array}$ & $\begin{array}{r}77 \\
.853\end{array}$ & $\begin{array}{l}83 \\
.911\end{array}$ \\
\hline
\end{tabular}

Notes: Unstandardized regression coefficients and standard errors in parentheses. ${ }^{* * *} p<.01,{ }^{* *} p<.05,{ }^{*} p<.10$. The units of analysis are country averages from 1990-2010. IGO membership, ENGO strength and commitment refer to country averages from 1990-2005. 


\section{Cumulative Effects of Democracy Quality Dimensions from 1950-2005/2010}

Following Fredriksson and Neumayer (2013), we tested the cumulative effects of the democracy quality dimensions. Table A10 uses the sum of the values of the democracy quality dimensions from 1950 to 2005 (dependent variable: commitment to international climate cooperation)/2010 (dependent variable: $\mathrm{CO}_{2}$ emissions per capita, In) as an independent variable. We come to the same conclusions as in our main analysis of the current values of the democracy quality dimensions. The long-term experience with political rights contributes to a commitment to climate cooperation. There are no significant effects of a country's historical experience with electoral and horizontal accountability or political and civil rights on climate policy outcomes.

Table A10. Democracy quality dimensions (cumulative effect from 1950-2010), commitment to climate cooperation and $\mathrm{CO}_{2}$ emissions per capita, In (OLS regression analysis).

\begin{tabular}{|c|c|c|c|c|}
\hline & $\begin{array}{l}\text { (1) Commitment } \\
\text { to climate } \\
\text { cooperation }\end{array}$ & $\begin{array}{c}\text { (2) Commitment to } \\
\text { climate cooperation } \\
\text { without influential } \\
\text { cases }\end{array}$ & $\begin{array}{l}\text { (3) } \mathrm{CO}_{2} \text { emissions } \\
\text { per capita, In }\end{array}$ & $\begin{array}{l}\text { (4) } \mathrm{CO}_{2} \text { emissions } \\
\text { per capita, In }\end{array}$ \\
\hline \multirow[t]{2}{*}{ Population density (In) } & .008 & $.013^{*}$ & $.080 * *$ & .049 \\
\hline & $(.010)$ & $(.007)$ & $(.037)$ & $(.035)$ \\
\hline \multirow[t]{2}{*}{ GDP per capita (In) } & -.002 & .008 & $.868 * * *$ & $.927 * * *$ \\
\hline & $(.016)$ & $(.011)$ & $(.063)$ & $(.060)$ \\
\hline \multirow[t]{2}{*}{ GDP per capita (In) squared } & & & $-.143 * * *$ & $-.116^{* * *}$ \\
\hline & & & $(.031)$ & $(.027)$ \\
\hline \multirow[t]{2}{*}{ GDP growth } & .006 & .002 & $-.096 * * *$ & $-.074 * *$ \\
\hline & $(.007)$ & $(.005)$ & $(.035)$ & $(.031)$ \\
\hline \multirow[t]{2}{*}{ Fuel exports (In) } & -.008 & .003 & $.274 * * *$ & $.210 * * *$ \\
\hline & $(.012)$ & $(.008)$ & $(.049)$ & $(.046)$ \\
\hline \multirow[t]{2}{*}{ Trade openness (In) } & $.091^{* *}$ & .129 & .168 & $.256^{* *}$ \\
\hline & $(.035)$ & $(.025)$ & $(.147)$ & $(.060)$ \\
\hline \multirow[t]{2}{*}{ Memberships in IGOs } & .000 & $.000 * *$ & $-.015^{* * *}$ & $-.009 * *$ \\
\hline & $(.001)$ & $(.001)$ & $(.004)$ & $(.004)$ \\
\hline \multirow[t]{2}{*}{ ENGO strength (In) } & $.036^{*}$ & .031 & $.186 * *$ & $.234 * * *$ \\
\hline & $(.021)$ & $(.015)$ & $(.083)$ & $(.071)$ \\
\hline \multirow[t]{2}{*}{ Climate change vulnerability } & -.029 & .026 & $-1.265 * * *$ & $-1.350 * * *$ \\
\hline & $(.099)$ & $(.065)$ & $(.410)$ & $(.373)$ \\
\hline \multirow[t]{2}{*}{ Commitment to climate cooperation } & & & .249 & .146 \\
\hline & & & $(.391)$ & $(.349)$ \\
\hline \multirow[t]{2}{*}{ Electoral accountability } & -.001 & -.004 & .001 & .000 \\
\hline & $(.004)$ & $(.003)$ & $(.004)$ & $(.004)$ \\
\hline \multirow[t]{2}{*}{ Horizontal accountability } & .001 & .001 & .001 & -.002 \\
\hline & $(.002)$ & $(.001)$ & $(.003)$ & $(.002)$ \\
\hline \multirow[t]{2}{*}{ Political rights } & $.007^{* *}$ & $.010 * * *$ & -.003 & -.003 \\
\hline & $(.003)$ & $(.002)$ & $(.003)$ & $(.003)$ \\
\hline \multirow[t]{2}{*}{ Civil rights } & .009 & .002 & .009 & .004 \\
\hline & $(.010)$ & $(.007)$ & $(.008)$ & $(.007)$ \\
\hline Countries & 99 & 78 & 98 & 87 \\
\hline $\mathrm{R}^{2}$ & .452 & .726 & .925 & .954 \\
\hline
\end{tabular}

Notes: Unstandardized regression coefficients and standard errors in parentheses. $* * * p<.01, * * p<.05, * p<.10$. The units of analysis are country averages from 1990-2005 (Model 1-2) and from 1990-2010 (Model 3-4). IGO membership, ENGO strength and commitment refer to country averages from 1990-2005. 


\section{Main Model of Commitment to Climate Cooperation with Interaction Effect between ENGO Strength and Political Rights}

We tested an interaction effect between ENGO strength and political rights (see table A11). The assumption is that political rights enable citizens to organize in ENGOs and exert influence via public opinion policy outputs. The results indicate no significant interaction effect between ENGO strength and political rights. It has to be considered that the number of ENGOs captures only the number of ENGO's in a country. However, alternative measures were only available for a limited number of countries.

Table A11. Interaction effect between ENGO strength and political liberties (OLS regression analysis).

\begin{tabular}{|c|c|c|}
\hline & (1) Commitment to climate cooperation & (2) $\mathrm{CO}_{2}$ emissions per capita, In \\
\hline Population density (In) & $\begin{array}{l}.007 \\
(.010)\end{array}$ & $\begin{array}{l}.088 * * \\
(.040)\end{array}$ \\
\hline GDP per capita (In) & $\begin{array}{l}.000 \\
(.017)\end{array}$ & $\begin{array}{l}.853^{* * *} \\
(.070)\end{array}$ \\
\hline GDP per capita (In) squared & & $\begin{array}{l}-.132^{* * *} \\
(.030)\end{array}$ \\
\hline GDP growth & $\begin{array}{c}.005 \\
(.007)\end{array}$ & $\begin{array}{l}.090 * * \\
(.088)\end{array}$ \\
\hline Fuel exports (In) & $\begin{array}{c}-.008 \\
(.012)\end{array}$ & $\begin{array}{l}.250 * * * \\
(.052)\end{array}$ \\
\hline Trade openness (In) & $\begin{array}{l}.086 * * \\
(.036)\end{array}$ & $\begin{array}{c}.082 \\
(.159)\end{array}$ \\
\hline Memberships in IGOs & $\begin{array}{c}.000 \\
(.001)\end{array}$ & $\begin{array}{l}-.014^{* * *} \\
(.004)\end{array}$ \\
\hline ENGO strength (In) & $\begin{array}{c}.036^{*} \\
(.021)\end{array}$ & $\begin{array}{c}.141 \\
(.086)\end{array}$ \\
\hline Climate change vulnerability & $\begin{array}{c}-.035 \\
(.100)\end{array}$ & $\begin{array}{c}-1.223^{* * *} \\
(.421)\end{array}$ \\
\hline Commitment to climate cooperation & & $\begin{array}{c}.547 \\
(.442)\end{array}$ \\
\hline Electoral accountability & $\begin{array}{c}-.013 \\
(.100)\end{array}$ & $\begin{array}{c}.344 \\
(.269)\end{array}$ \\
\hline Horizontal accountability & $\begin{array}{c}.010 \\
(.032)\end{array}$ & $\begin{array}{l}-.030 \\
(.030)\end{array}$ \\
\hline Political rights & $\begin{array}{c}.100^{*} \\
(.050)\end{array}$ & $\begin{array}{l}-.236 \\
(.216)\end{array}$ \\
\hline Civil rights & $\begin{array}{c}-.020 \\
(.029)\end{array}$ & $\begin{array}{c}.377 \\
(.680)\end{array}$ \\
\hline ENGOInXpolitical rights & $\begin{array}{l}-.020 \\
(.029)\end{array}$ & $\begin{array}{l}.045 \\
(.127)\end{array}$ \\
\hline $\begin{array}{l}\text { Countries } \\
\mathrm{R}^{2}\end{array}$ & $\begin{array}{l}99 \\
.455\end{array}$ & $\begin{array}{l}99 \\
.918\end{array}$ \\
\hline
\end{tabular}

Notes: Unstandardized regression coefficients and standard errors in parentheses. ${ }^{* * *} p<.01,{ }^{* *} p<.05,{ }^{*} p<.10$. The units of analysis are country averages of from 1990-2005 (Model 1) and from 1990-2010 (Model 2). IGO membership, ENGO strength and commitment refer to country averages from 1990-2005. 


\section{COGITATIO}

\section{Control of Annex-I Status}

International climate change regime distinguishes between Annex-I and non-Annex-I countries. Annex-I (Developed) countries are regarded as historically responsible for global warming and, therefore, should take the lead in climate change mitigation. Thereby, the Kyoto Protocol specified legally binding greenhouse gas emissions targets for Annex-I member states. Table A12 controls the effect of the Annex-I status on commitment to climate cooperation. Overall, our results remain stable.

Table A12. Annex-I status and commitment to climate cooperation (OLS regression analysis).

(1) Commitment to climate cooperation

\begin{tabular}{|c|c|}
\hline Population density (In) & $\begin{array}{l}.007 \\
(.010)\end{array}$ \\
\hline GDP per capita (In) & $\begin{array}{c}-.006 \\
(.018)\end{array}$ \\
\hline GDP per capita (In) squared & $\begin{array}{c}.007 \\
(.008)\end{array}$ \\
\hline GDP growth & $\begin{array}{c}.007 \\
(.008)\end{array}$ \\
\hline Fuel exports (In) & $\begin{array}{c}-.007 \\
(.012)\end{array}$ \\
\hline Trade openness (In) & $\begin{array}{l}.092 * * \\
(.035)\end{array}$ \\
\hline Memberships in IGOs & $\begin{array}{c}.000 \\
(.000)\end{array}$ \\
\hline ENGO strength (In) & $\begin{array}{c}.038^{*} \\
(.021)\end{array}$ \\
\hline Climate change vulnerability & $\begin{array}{c}.003 \\
(.115)\end{array}$ \\
\hline Electoral accountability & $\begin{array}{l}-.007 \\
(.060)\end{array}$ \\
\hline Horizontal accountability & $\begin{array}{c}.009 \\
(.032)\end{array}$ \\
\hline Political rights & $\begin{array}{l}.102 * * \\
(.050)\end{array}$ \\
\hline Civil rights & $\begin{array}{l}.12 \\
(.159)\end{array}$ \\
\hline Annex I country & $\begin{array}{c}.026 \\
(.048)\end{array}$ \\
\hline $\begin{array}{l}\text { Countries } \\
\mathrm{R}^{2}\end{array}$ & $\begin{array}{r}99 \\
.454\end{array}$ \\
\hline
\end{tabular}
are country averages of from 1990-2005. 


\section{COGITATIO}

\section{Control of $\mathrm{CO}_{2}$ Emissions Per Capita}

Table $\mathrm{A} 13$ adds $\mathrm{CO}_{2}$ emissions per capita, In, as an additional control variable in our analysis of commitment to climate change cooperation. Countries with low emission levels might be more willing to enter international climate change treaties than countries with high emission levels. The results of our main model in Table 2 remain stable. In contrast with our expectations, we find a positive but insignificant effect of $\mathrm{CO}_{2}$ emission per capita on commitment to climate cooperation.

Table A13. Democracy quality dimensions and commitment to climate cooperation (OLS regression analysis).

(1) Commitment to climate cooperation

\begin{tabular}{|c|c|}
\hline Population density (In) & $\begin{array}{c}.005 \\
(.010)\end{array}$ \\
\hline GDP per capita (In) & $\begin{array}{c}-.025 \\
(.026)\end{array}$ \\
\hline GDP growth & $\begin{array}{l}.008 \\
(.008)\end{array}$ \\
\hline Fuel exports (In) & $\begin{array}{c}-.015 \\
(.014)\end{array}$ \\
\hline Trade openness (In) & $\begin{array}{l}.084 * * \\
(.036)\end{array}$ \\
\hline Memberships in IGOs & $\begin{array}{c}.000 \\
(.000)\end{array}$ \\
\hline ENGO strength (In) & $\begin{array}{c}.031 \\
(.021)\end{array}$ \\
\hline Climate change vulnerability & $\begin{array}{c}-.004 \\
(.102)\end{array}$ \\
\hline Electoral accountability & $\begin{array}{c}-.026 \\
(.062)\end{array}$ \\
\hline Horizontal accountability & $\begin{array}{c}.017 \\
(.032)\end{array}$ \\
\hline Political rights & $\begin{array}{l}.107^{* *} \\
(.049)\end{array}$ \\
\hline Civil rights & $\begin{array}{c}.135 \\
(.158)\end{array}$ \\
\hline $\mathrm{CO}_{2}$ emissions per capita, In & $\begin{array}{c}.026 \\
(.024)\end{array}$ \\
\hline $\begin{array}{l}\text { Countries } \\
\mathrm{R}^{2}\end{array}$ & $\begin{array}{r}99 \\
.460\end{array}$ \\
\hline
\end{tabular}




\section{Democracy Quality Dimensions and Average $\mathrm{CO}_{2}$ Emissions in Two Sub-Periods (1990-1999, 2000-2010)}

We also estimated our climate policy outcome model for two sub-periods-1990-1999 and 2000-2010. Table A13 shows, as in our main analysis, no significant effects of the democracy quality dimensions on $\mathrm{CO}_{2}$ emissions per capita. Model 2 and 4 in table A13 show that the significant positive effect of electoral accountability in the analysis of our sample without countries from the Middle East and Northern Africa is only stable for the period from 1990-1999.

Table A14. Democracy quality dimensions and $\mathrm{CO}_{2}$ emissions per capita, In (OLS regression analysis).

\begin{tabular}{|c|c|c|c|c|}
\hline & (1) 1990-1999 & $\begin{array}{l}\text { (2) 1990-1999 } \\
\text { Without countries } \\
\text { from Middle East } \\
\text { and North Africa }\end{array}$ & (3) 2000-2010 & $\begin{array}{l}\text { (4) } 2000-2010 \\
\text { Without countries } \\
\text { from Middle East } \\
\text { and North Africa }\end{array}$ \\
\hline \multirow[t]{2}{*}{ Population density (In) } & $.077^{*}$ & $.084^{*}$ & $.093 * *$ & $.098 * *$ \\
\hline & $(.046)$ & $(.046)$ & $(.045)$ & $(.046)$ \\
\hline \multirow[t]{2}{*}{ GDP per capita (In) } & $.861 * * *$ & $.858 * * *$ & $.942 * * *$ & $.927^{* * *}$ \\
\hline & $(.074)$ & $(.074)$ & $(.074)$ & $(.078)$ \\
\hline \multirow[t]{2}{*}{ GDP per capita (In) squared } & $-.114^{* * *}$ & $-.098 * * *$ & $-.137 * * *$ & $-.129 * * *$ \\
\hline & $(.032)$ & $(.033)$ & $(.031)$ & $(.033)$ \\
\hline \multirow[t]{2}{*}{ GDP growth } & $-.094 * * *$ & $-.096 * * *$ & .008 & -.002 \\
\hline & $(.023)$ & $(.023)$ & $(.043)$ & $(.049)$ \\
\hline \multirow[t]{2}{*}{ Fuel exports (In) } & $.185^{* * *}$ & $.213^{* * *}$ & $.216^{* * *}$ & $.233^{* * *}$ \\
\hline & $(.056)$ & $(.056)$ & $(.057)$ & $(.060)$ \\
\hline \multirow[t]{2}{*}{ Trade openness (In) } & .066 & .065 & .022 & -.017 \\
\hline & $(.158)$ & $(.157)$ & $(.169)$ & $(.172)$ \\
\hline \multirow[t]{2}{*}{ Memberships in IGOs } & $-.016 * * *$ & $-.018 * * *$ & $-.011 * *$ & $-.013^{* *}$ \\
\hline & $(.004)$ & $(.005)$ & $(.005)$ & $(.005)$ \\
\hline \multirow[t]{2}{*}{ ENGO strength (In) } & $.166^{*}$ & .144 & .106 & .099 \\
\hline & $(.098)$ & $(.099)$ & $(.083)$ & $(.085)$ \\
\hline \multirow[t]{2}{*}{ Climate change vulnerability } & $-1.105^{* * *}$ & $-1.050 * *$ & $-1.052^{* *}$ & $-1.046^{* *}$ \\
\hline & $(.463)$ & $(.460)$ & $(.455)$ & $(.466)$ \\
\hline \multirow[t]{2}{*}{ Commitment to climate cooperation } & .866 & .728 & .736 & .659 \\
\hline & $(.527)$ & $(.524)$ & $(.469)$ & $(.480)$ \\
\hline \multirow[t]{2}{*}{ Electoral accountability } & .361 & $.486^{*}$ & .061 & .150 \\
\hline & $(.137)$ & $(.281)$ & $(.259)$ & $(.278)$ \\
\hline \multirow[t]{2}{*}{ Horizontal accountability } & -.135 & -.218 & -.016 & -.046 \\
\hline & $(.137)$ & $(.141)$ & $(.143)$ & $(.147)$ \\
\hline \multirow[t]{2}{*}{ Political rights } & -.150 & .053 & -.333 & $-.284 * *$ \\
\hline & $(.232)$ & $(.246)$ & $(.241)$ & $(.251)$ \\
\hline \multirow[t]{2}{*}{ Civil rights } & .532 & .220 & .811 & .773 \\
\hline & $(.680)$ & $(.688)$ & $(.781)$ & $(.792)$ \\
\hline Countries & 90 & 87 & 95 & 92 \\
\hline $\mathrm{R}^{2}$ & .914 & .919 & .907 & .907 \\
\hline
\end{tabular}

Notes: Unstandardized regression coefficients and standard errors in parentheses. ${ }^{* * *} p<.01, * * p<.05, * p<.10$. The units of analysis are country averages of from 1990-1999 (Model 1-2) and from 2000-2010 (Model 3-4). IGO membership, ENGO strength and commitment refer to country averages from 1990-2005. 


\section{COGITATIO}

\section{Democracy Quality Dimensions and Changes in $\mathrm{CO}_{2}$ Emissions over Time}

\subsection{Dependent Variable: Linear Trend in $\mathrm{CO}_{2}$ Emissions Per Capita from 1990 to 2010}

Our main analysis focuses on variation in $\mathrm{CO}_{2}$ emissions per capita among countries. Table A15 tests our model on the variation of long-term changes in $\mathrm{CO}_{2}$ emissions among countries. For this purpose, we estimated for each country the slope (unstandardized regression coefficient) of our year variable on $\mathrm{CO}_{2}$ emissions per capita from 1990-2010. The slopes of each country constitute our measure of long-term changes in $\mathrm{CO}_{2}$ emissions per capita in the cross-sectional OLS regression analysis (slope regression) in Table A15 (Babones, 2014). We find no significant effect of the democracy quality dimensions on the linear trend of $\mathrm{CO}_{2}$ emissions per capita.

Table A15. Democracy quality dimensions and $\mathrm{CO}_{2}$ emissions per capita, In long-term changes (OLS regression analysis/slope regression).

\begin{tabular}{|c|c|}
\hline & (1) \\
\hline Population density (In) & $\begin{array}{c}-.003 \\
(.011)\end{array}$ \\
\hline GDP per capita (In) & $\begin{array}{c}.030 \\
(.020)\end{array}$ \\
\hline GDP per capita (In) squared & $\begin{array}{c}.001 \\
(.008)\end{array}$ \\
\hline GDP growth & $\begin{array}{l}.027^{* * *} \\
(.010)\end{array}$ \\
\hline Fuel exports (In) & $\begin{array}{c}.020 \\
(.015)\end{array}$ \\
\hline Trade openness (In) & $\begin{array}{c}-.085^{*} \\
.045)\end{array}$ \\
\hline Memberships in IGOs & $\begin{array}{c}-.001 \\
(.001)\end{array}$ \\
\hline ENGO strength (In) & $\begin{array}{c}-.049 * \\
(.025)\end{array}$ \\
\hline Climate change vulnerability & $\begin{array}{l}.343^{* * *} \\
(.120)\end{array}$ \\
\hline Commitment to climate cooperation & $\begin{array}{c}.033 \\
(.125) \\
\end{array}$ \\
\hline Electoral accountability & $\begin{array}{l}.030 \\
(.077)\end{array}$ \\
\hline Horizontal accountability & $\begin{array}{c}.018 \\
(.039)\end{array}$ \\
\hline Political rights & $\begin{array}{c}.048 \\
(.061)\end{array}$ \\
\hline Civil rights & $\begin{array}{c}-.164 \\
(.193)\end{array}$ \\
\hline $\begin{array}{l}\text { Countries } \\
\mathrm{R}^{2}\end{array}$ & $\begin{array}{l}99 \\
.266\end{array}$ \\
\hline
\end{tabular}




\subsection{Dependent Variable: Annual Changes in $\mathrm{CO}_{2}$ Emissions Per Capita}

We estimated pooled OLS regression models with annual changes of $\mathrm{CO}_{2}$ emission per capita as a dependent variable (first differences) with country and year dummies. As we have only annual data on state memberships in IGOs and the number of ENGOs in a country until 2005, these models only analyze the $\mathrm{CO}_{2}$ emission changes from 1990-2005. Table A15 finds no effect of the institutional traits of democracy on annual changes in $\mathrm{CO}_{2}$ emission per capita.

Table A16. Democracy quality dimensions and $\mathrm{CO}_{2}$ emissions per capita, In short-term changes (OLS regression analysis/slope regression).

\begin{tabular}{lc}
\hline & $(1)$ \\
\hline Population density (In) & -.039 \\
GDP per capita (In) & $.081)$ \\
& -.005 \\
GDP per capita (In) squared & $(.043)$ \\
& -.005 \\
GDP growth & $(.010)$ \\
& $.006 * * *$ \\
Fuel exports (In) & $(.001)$ \\
& .000 \\
Trade openness (In) & $(.008)$ \\
& .000 \\
Memberships in IGOs & $(.000)$ \\
& -.000 \\
ENGO strength (In) & $(.001)$ \\
& .002 \\
Electoral accountability & $(.012)$ \\
& .008 \\
Horizontal accountability & $(.018)$ \\
Political rights & .012 \\
& $(.017)$ \\
Civil rights & -.034 \\
& $(.029)$ \\
Observations & .050 \\
\hline Notes: Unstandardized regression coefficients and standard errors in parentheses. ${ }^{* * *} p<.01, * * p<.05, * p<.10$. \\
\end{tabular}

\section{References}

Babones, S. J. (2014). Methods for quantitative macro-comparative research. Los Angeles, CA: Sage.

Coppedge, M., Gerring, J., Lindberg, S., Skaaning, S.-E., Teorell, J., Altman, D., . . . Wilson, S. (2017). V-Dem [country-year/country-date] dataset v7.1. Varieties of Democracy (V-Dem) Project. Retrieved from https://www.vdem.net/en/data/data-version-7-1

Fredriksson, P. G., \& Neumayer, E. (2013). Democracy and climate change policies. Is history important? Ecological Economics, 95, 11-19.

Marshall, M. G., Gurr, T. R., \& Jaggers, K. (2016). Polity IV project, political regime characteristics and transitions, 1800-2015. Center for Systemic Peace. Retrieved from http://www.systemicpeace.org/inscrdata.html

Merkel, W. (2004). Embedded and defective democracies. Democratization, 11(5), 33-58.

Pemstein, D., Marquardt, K. L., Tzelgov, E., Wang, Y., Krusell, J., \& Miri, F. (2017). The V-Dem measurement model: Latent variable analysis for cross-national and cross-temporal expert-coded data (Working Paper no. 21, 2nd ed.). Gothenburg: Varieties of Democracy Institute. 